\title{
TRADICIJSKO ODIJEVANJE I TEKSTILNO RUKOTVORSTVO
}

\author{
Aleksandra VLATKOVIĆ \\ Antuna Šoljana 6 \\ 10000 Zagreb
}

\section{UVOD}

U poglavlju o tradicijskom odijevanju i tekstilnom rukotvorstvu Krivopućana bit će opisani: materijali za izradu odjeće, muška i ženska odjeća, obuća, uporabni tekstil (torbe), te ženski ručni rad (pletenje, vezenje, kukičanje i sl.). ${ }^{1}$ Opisi tradicijske odjeće u tekstu odnosit će se na razdoblje od početka 20. stoljeća do četrdesetih godina 20. stoljeća.

Podaci i sjećanja o odijevanju na području Krivoga Puta malobrojni su, jer su odjevni predmeti domaće proizvodnje za većinu Krivopućana prošlost koje se oni vrlo slabo sjećaju: o tradicijskim odjevnim predmetima većina ljudi čula je od starijih generacija ${ }^{2}$, dok su sami upotrebljavali vrlo malo predmeta domaće proizvodnje.

Obzirom da je ova tema slabo istražena ovo istraživanje se uglavnom temelji na kazivanjima Krivopućana. Kao osnova i izvor za ispitivanje kazivača o temi odijevanja i tekstilnog rukotvorstva poslužile su mi Upitnice Etnološkog atlasa (UEA) pohranjene u Arhivu Odsjeka za etnologiju i kulturnu antropologiju Filozofskog fakulteta u Zagrebu, koje sam tijekom istraživanja navedene teme proširivala ili reducirala ovisno o zahtjevima pojedinih dijelova teme. ${ }^{3} \mathrm{U}$ Arhivu se nalaze i ispunjene Upitnice za selo (mjesto) Krivi Put koje sam koristila za potrebe ovog istraživanja. ${ }^{4}$ Podatke iz Upitnica u tekstu navodim i kompariram $s$ podacima na koje sam naišla prilikom vlastitog terenskog istraživanja odijevanja i tekstilnog rukotvorstva na području Krivoga Puta.

Problem u kompariranju predstavljaju, kako nepreciznost lociranja pojava u vremenu i prostoru u UEA, tako i činjenica da se podaci navode za naselje Krivi Put općenito, bez preciziranja u kojim se zaselcima ispitivalo, te na koje se vrijeme podaci odnose. Ipak, u nedostatku drugih izvora, podaci iz Upitnice poslužili su kao potvrda ili naznaka mogućih odstupanja i razlika u odnosu na podatke prikupljene vlastitim istraživanjem.

Još jedan nedostatak upitničke građe (prikupljanje tijekom šezdesetih godina 20. stoljeća) jest da sadržavaju i „prazna mjesta“ - nedostatak podataka, a za koje ne znamo jesu li ispitani ili ih se nije detaljnije istraživalo.

Pored toga, odjevne predmete, koji su još u prvoj polovici 20. stoljeća činili sastavni dio tradicijskog odijevanja Bunjevaca, većina Krivopućana ne doživljava kao kulturnu sastavnicu vrijednu isticanja. Na-

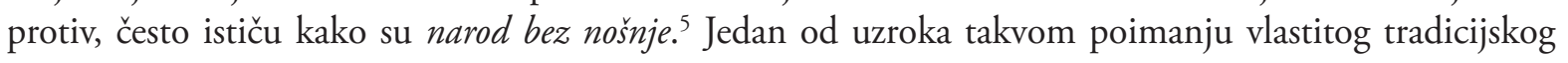

1 Tema odijevanja i tekstilnog rukotvorstva istraživana je 2003. godine u naseljima i zaselcima senjskoga zaleđa: Gorica, Katići, Krivi Put, Lucići, Matići, Mrzli Dol, Pavelići, Pavići, Provoz, Rusova Draga, Serdari, Stanić Brig, Škopci, Šojatski Dolac i Veljun. Iste godine ova je tema istražena i na području Senjskoga bila, a rad naslova Odijevanje i tekstilno rukotvorstvo primorskih Bunjevaca objavljen je u Senjskom zborniku, 30, 2003, str. 587-628.

2 Pod pojmom „starija generacija“ misli se na roditelje kazivača rođenih tridesetih i četrdesetih godina 20. stoljeća.

3 Ovaj je prilog, kako je već spomenuto, u izmijenjenom i sažetijem obliku, prethodno objavljen u Senjskom zborniku. $\mathrm{Na}$ kraju tog rada, kao prilog, nalazi se i Upitnica prema kojoj se ispitivalo na terenu, a koja čini proširenu verziju Upitnice Etnološkog atlasa, signatura UEA Fd 241/610 i Fd 241/651.

4 Ne može se sa sigurnošču reči odnose li se podaci u Upitnici odnose na zaselak Krivi Put ili istoimeno naselje. (UEA Fd 241/610 i Fd 241/651.

5 O odijevanju kao dijelu primorsko-bunjevačkog identiteta vidi: Škrbić-Alempijević, Nevena (2003): Prilozi poznavanju primorsko-bunjevačkog identiteta, Senjski zbornik 30, Senj, 425-444. 
odijevanja mogao bi biti i stalan doticaj i uspoređivanje s gradskom odjećom karakterističnom za grad Senj kao i s bogato ukrašenim ličkim odjevnim predmetima. Naime, odjeća na ovom području jest jednostavna i bez puno ukrasa (ukrasi na svakodnevnoj, radnoj i blagdanskoj odjeći nisu se previše razlikovali). Osnovna razlika je ta što se, u vrijeme kada se tradicijska odjeća još uvijek koristila, na blagdan ipak nije nosila odjeća domaće proizvodnje, već kupovna. Razlog tome je i stav ljudi prema odjeći domaće proizvodnje koja je shvaćana manje vrijednom od kupovne. Djelomičan uzrok takvom stavu vjerojatno je i posredovanje medija (novine i televizija) putem kojih se selektivno primaju informacije o tradicijskom odijevanju drugih krajeva Hrvatske, te time gradi vlastita spoznaja o tome što je narodna nošnja i što je naša nošnja. Nošnjom stanovništvo Krivoga Puta uglavnom smatra bogate slavonske varijante tradicijskog odijevanja, u usporedbi s kojima tradicijska odjeća Krivoga Puta djeluje skromno. Tako se u razgovorima o tradicijskoj odjeći često može čuti da nije ko po Slavoniji ${ }^{6}$, odnosno da tu narod nema neke posebne narodne nošnje, to nije uobičajeno za ove krajeve ${ }^{7}$ ili da se normalno uvijek oblačilo, a tamo po Liki i okolo to su bile više narodne nošnje. ${ }^{8}$

U odnosu na Senj često se može čuti da su oni vaj po Senju bili, kako bi rekla, kao bolje obučeni. E, a sa sela je dolazio kako je ko moga. Kako je ko ima.'

Stoga kazivanje Stjepana Prpića Stipine iz Gorice najbolje opisuje stav Krivopućana o onomu što smatraju tradicijskim: Tu tradicije neke nema, čak nismo donijeli ni narodnu nošnju, ni običaje. ${ }^{10}$

Dosad se temom odijevanja primorskih Bunjevaca podrobnije bavila etnologinja Marijana Gušić te objavila rad Odjeća Senjskih Uskoka i Bunjevaca, kojim predstavlja rekonstrukciju narodne nošnje za izložbeni postav u Nehaj-gradu. ${ }^{11}$ Kao glavni izvor za rekonstrukciju bunjevačke nošnje autorici su poslužile četiri ilustracije iz djela Das was verschwindet autora J. L. Salvatora, izdanog u Leipzigu 1905. godine. Uz ilustracije se navodi kako iste prikazuju ljude iz okolice Senja, ali ne i to da su oni Bunjevci. Autori ovih ilustracija strani su slikari pa bi ilustracije trebalo promatrati s oprezom, uzeti u obzir vjerojatnost romantičarskog slikarskog prikazivanja (egzotiziranja) te ih ne tretirati kao glavni izvor podataka u prikazu odijevanja ovog kraja. ${ }^{12}$

\section{SIROVINE ZA IZRADU ODJEVNIH PREDMETA}

\subsection{VUNA, LAN I KONOPLJA}

$\mathrm{T}$ ijekom prve polovice 20. stoljeća na području Krivoga Puta odjevni su predmeti najviše izrađivani od vune. Nakon što su vunu prvo ostrigli ${ }^{13}$, nekoliko puta bi se dobro oprala u vodi, te bi se potom odijelila ovčja od janjeće vune. Ovčja vuna je grublja i koristila se za izradu svakodnevnih i radnih odjevnih predmeta, kao i za izradu šarenica (prekrivača za krevete i zid, sl. 13), biljaca - vunenih pokrivača, (sl. 12), i sličnih predmeta. Janjeća vuna je mekša i koristila se za izradu finijih odjevnih predmeta, za bolju i svečaniju odjeću.

Ljudi su se okupljali na prelima gdje bi žene, sjedeći na zemlji, vunu prvo raščupale rukama, a zatim obradile, vlačile, na gargašama (češljevima (sl. 1) a potom je smotali u kudilju (smotuljak), nakon čega je bila spremna za predenje.

Anka Tomljanović Zekanova, Matići.

Josip Blažević Ivela, Stanić Brig.

Katica Hotlovec, Krivi Put.

Ista kazivačica, Krivi Put.

O načinu odijevanja kao čimbeniku identifikacije za područje Senjskog bila više vidi u: Škrbić Alempijević (2003).

11 Za kratak osvrt, te komparaciju podataka iz teksta M. Gušić s onim dobivenim terenskim istraživanjima na području Krivoga Puta i Senjskoga bila vidi u: Vlatković (2003).

12 Slikari ovih ilustracija bili su: Franz Bohumil Doubek, Paol Joanowits, Emil Lauffer, Peter Maixner i Guido Manes.

13 Striženje (šišanje) ovaca obavljalo se na Duhove o čemu su Krivopćani spjevali i bećarac: Na Duhove šišaju se ovce, bješte cure makar za udovce! Iz transkripata Marijete Rajković, a prema kazivanju Milana Tomljanovića Periše iz Zamalića. 


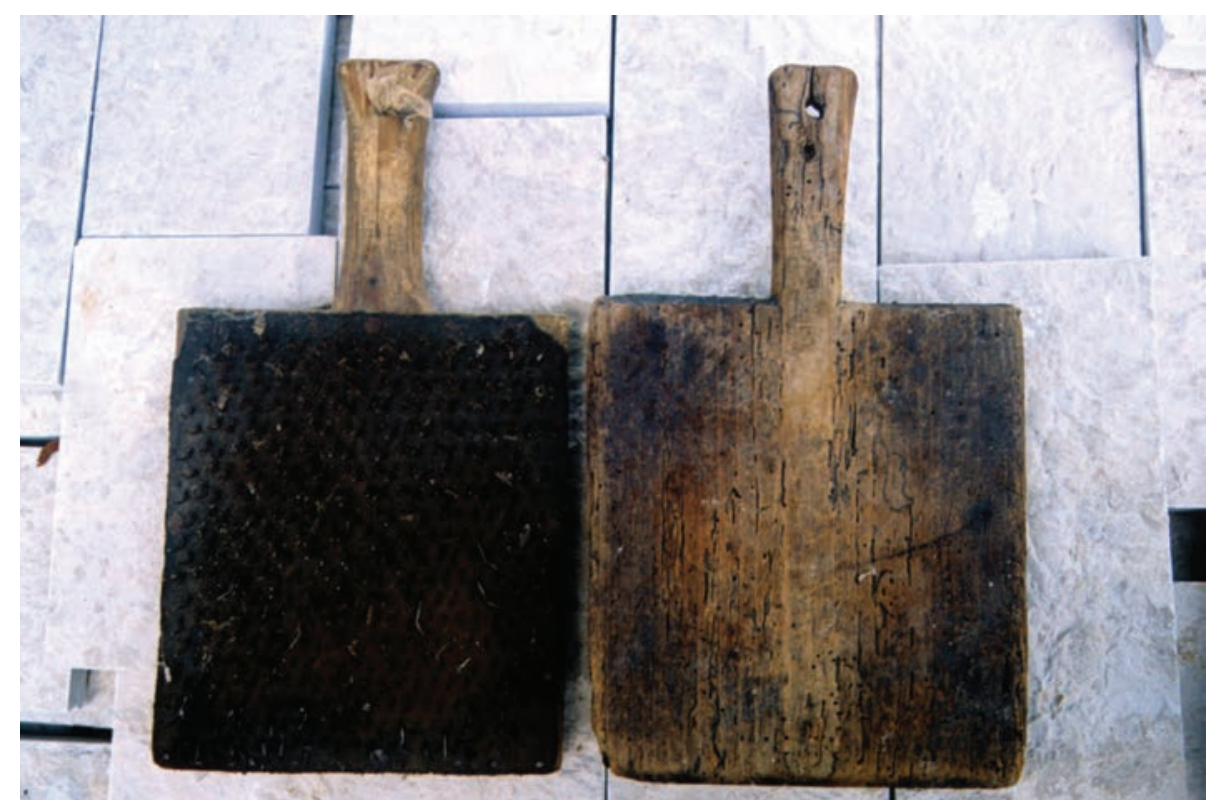

Slika 1: Gargaše, vlasništvo obitelji Tomljanovic Zekanovi, Matiči; snimio Augustin Perić, lipanj 2003.

Ispredenu vunu, ukoliko je nisu nosili na bojanje, motali su u klupka. Ako su vunu nosili bojati, motali su je na raškove (štap visine oko 1 metar koji na jednom kraju ima horizontalnu daščicu, a na drugom prirodnu rašlju) (sl. 7). Vunu su koristili uglavnom za pletenje odjevnih predmeta poput maja (muški i ženski pleteni džemperi s rukavima), pulovera (muški džemperi bez rukava), bušta (ženski džemperi bez rukava), čarapa, papuča, šalova, rukavica, manica (odjevni predmet za muškarce sličan rukavicama) i štrimfi ili natikača (odjevni predmet za muškarce sličan čarapama). Izrađivali su i predmete od tkane vune, poput hlača, ćurka (kraći kaput), ćerme (prsluk), te biljaca i šarenica, pokrivača za krevet. Vunu su bojali kupovnim bojama, karticama, ali i s lišćem, korom oraha, tabakom (duhanom), jasenovom korom i rušvicom (vrsta biljke, grm).

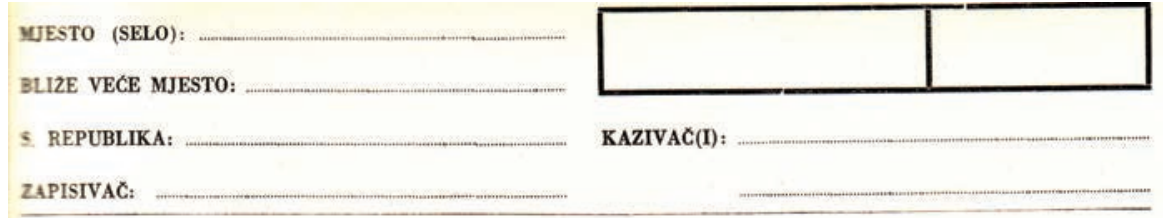

\section{STUPE, TRLICE}

1. Kojim se načinom priređuje za predenje močeni $\mathbf{i}$ osušeni lan, konoplja ili žuka (brnestra), možda i kopriva: lomljenjem i guljenjem stabljika rukama (naziv za to?), lupanjem (pratljačom i sl.), udaranjem drvenim nožem u procjepu (procap) ili između dva duga kamena, lomljenjem u stupi na vodu ili trenjem pod kamenim tijeskom (toč, torkul), udaranjem u stupi (mužaru) maljem, tučenjem (stupanjem, nabijanjem ili?) u nožnoj stupi, trenjem na trlici ili kako drukěije? Upotrebljava li se više tih sprava jedna za drugom (koje i kojim redom, koje kod lana, koje kod konoplje?)?

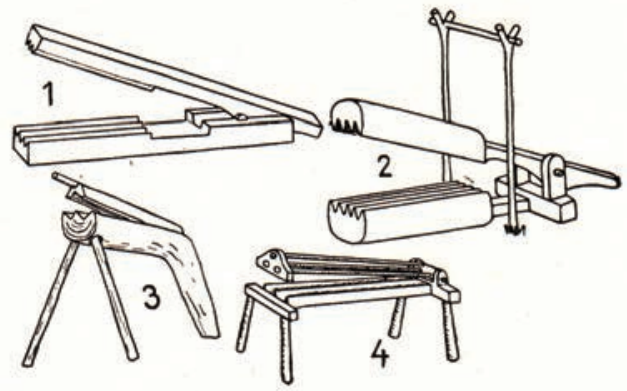

2. Kakva je sprava (stupa, stupka, tukača ili?) za prvo tučenje, kao na sl. 1-4 ili kako drukčije (nacrtati!)? Ima li uzdužne žljebo-

37

Slika 2: Preslika nožne stupe iz. Upitnice Etnološkog atlasa br. 3, str. 37, sl.1.; Arbiv Odsjeka za etnologiju i kulturnu antropologiju, Filozofski fakultet Sveucilista u Zagrebu. 


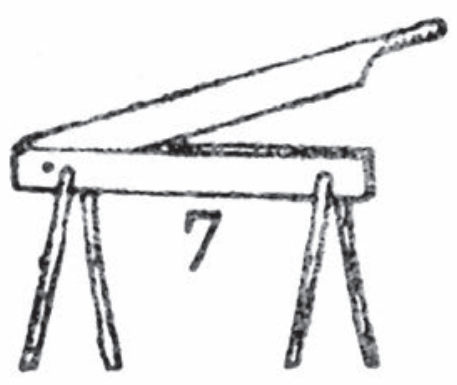

Slike 3: Preslika trlice iz Upitnice Etnološkog atlasa br. 3, str. 38, sl. 7.; Arbiv Odsjeka za etnologiju i kulturnu antropologiju, Filozofski fakultet Sveucilišta u Zagrebu.

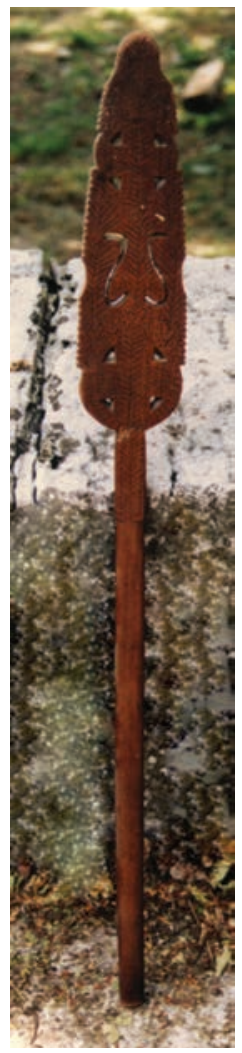

Na području Krivoga Puta, pretežno do Drugoga svjetskog rata, uzgajani su konoplja i lan. Od ovih sirovina izrađivani su: ženske donje košulje, muške donje gaće, plahte, posteljine i ručnici. ${ }^{14}$

Prema podacima iz Upitnice postupak obrade konoplje i lana obuhvaćao je prvo obradu priređenih rukoveti (snopova) na nožnoj stupi (sl. 2) zatim na trlici (sl. 3), te doradu na sabljici. ${ }^{15}$ Tako obrađena, ostupana $i$ otrta rukovet lana i konoplje nazivana je povesmo, dok je za otpad zabilježen naziv posder. Povesmo se dodatno obrađivalo pomoću grebenova, grebenanjem, nakon čega se opet isabljiča, obradi na sabljici.

Sljedeća faza u obradi lana i konoplje bila je predenje. Prele su isključivo žene. Preslice su bile kopljastog tipa, od javorova drveta i ukrašene rezbarijama koje su izrađivali muškarci. (sl. 4) Nit se ispredala i na kolovratu u koji je bila zataknuta preslica. ${ }^{16}$ (sl. 5) Ispredena nit namatana je na vreteno (sl. 6) s kojeg se prematala u pasmo na raškove. (sl. 7) Nit su zatim pripremali za snovanje namotavši je u klupko pomoću vitla ili na cjevčice, pomoću letnjaka. ${ }^{17}$ (sl. 8)

Slika 4: Preslica, vlasnik Milan Tomljanović Ivić, Cupići; snimio

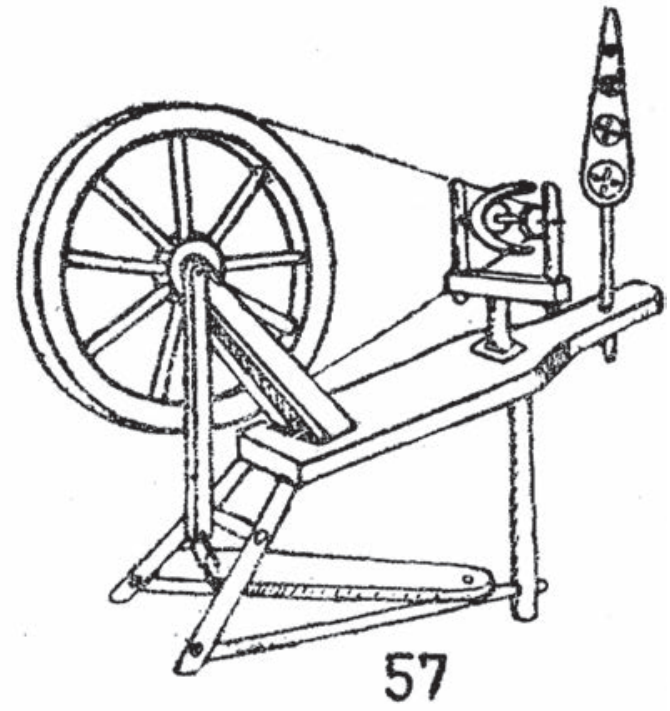

Slika 5: Preslika kolourata iz Upitnice Etnološkog atlasa br. 3, str. 46, sl. 57; Arbiv Odsjeka za etnologiju $i$ kulturnu antropologiju, Filozofski fakultet Sveučilišta u Zagrebu. Augustin Peric, lipanj 2003.

14 Kako na terenu nisu istraženi podaci o obradi konoplje i lana, podaci u tekstu temelje se na podacima iz Upitnice Etnološkog atlasa (UEA, III, 88, Fd 241/651).

15 U Upitnici se ne definira pojam sabljica. S obzirom na pitanje, sabljica je drvo, kolac ili daska na kojoj se dorađivala rukovet udaranjem o sabljicu.

16 Preslice su bile kopljastog tipa, a koristile su se i za vunu i za lan. (UEA, III, 90, Fd 241/651)

17 UEA, III, 91, Fd 241/651. 


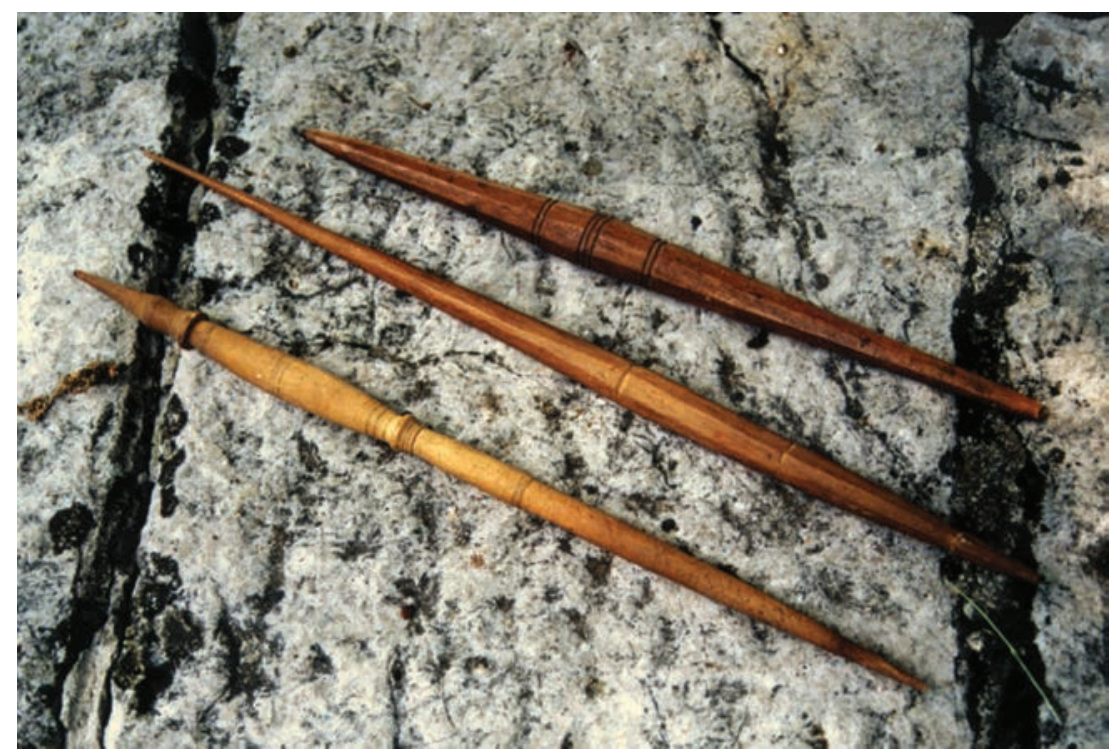

Slika 6: Vretena, vlasnik Milan Tomljanović Ivić, Cupić; snimio Augustin Perić, lipanj 2003. godine.

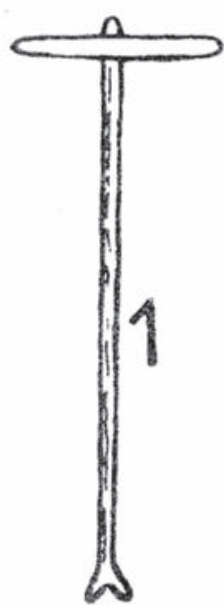

Slika 7: Preslika raške iそ. Upitnice Etnološkog atlasa br. 3, str. 47, sl. 1; Arbiv Odsjeka za etnologiju i kulturnu antropologiju, Filozofski fakultet Sveučilišta u Zagrebu.

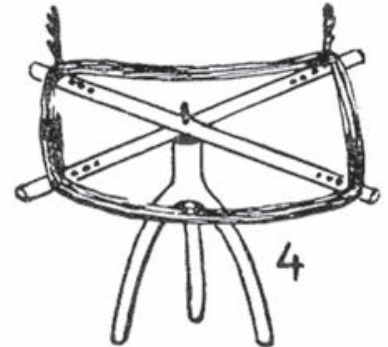

Slika 8: Preslika vitla iz Upitnice Etnološkog atlasa br. 3, str. 48, sl. 4; Arbiv Odsjeka za etnologiju i kulturnu antropologiju, Filozofski fakultet Sveucilista u Zagrebu.
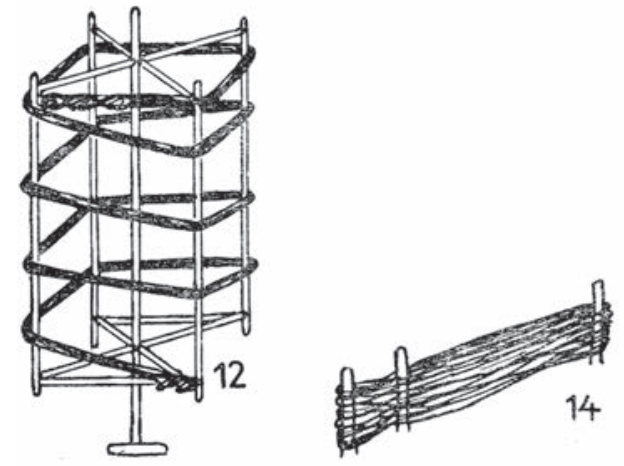

Slika 9: Preslika kolčice (sl. 14) i snovače (sl. 12) iz. Upitnice Etnološkog atlasa br. 3, str. 49; Arbiv Odsjeka za etnologiju i kulturnu antropologiju, Filozofski fakultet Sveučilista u Zagrebu. 
Slijedila je priprema niti osnove za tkanje snovanjem. Kao stariji $^{18}$ način snovanja u UEA navodi se snovanje pomoću kolčica, štapova, (sl. 9), dok je kao noviji ${ }^{19}$ zabilježen onaj pomoću snovače (sl. 9). Snovane niti slažu se u pasma, a jedno pasmo čini 30 žica. ${ }^{20} \mathrm{Za}$ tkanje se koristio horizontalni tkalački stan - tara. Isti tip koristio se za tkanje vunom, lanom i konopljom svih dijelova tkane odjeće. Vunu, lan i konoplju žene su nosile tkati u Liku kod pravoslavki, Vlainja ${ }^{21}$. Sirovina za tkanje najčešće se nosila tkaljama u: Vratnik, Brinje, Brlog, Otočac, Prokike, Ritavac, Grabovu Lokvu, Brlog i Krasno.

Žene koje su se bavile tkanjem na području samog Krivoga Puta bile su Ličanke, ne primorske Bunjevke, a vještinom tkanja ovladale su u roditeljskom domu, prije udaje. ${ }^{22}$

Otkanu vunu nosili su na valjanje u Švicu, na rijeku Gacku. ${ }^{23}$ Usluge valjanja i tkanja plaćali su isključivo novcem jer je Lika po svemu bila bogatije područje od onoga na kojem su živjeli primorski Bunjevci.

\subsection{KOŽA}

$\mathrm{K}$

oža je, uz vunu, lan i konoplju, bila vrlo važan materijal za izradu odjevnih predmeta na ovom području. Sirovu kožu ljudi su za daljnju uporabu prerađivali strojenjem. Kožu je strojio tko je u tome bio vještiji, kod kuće, kukuruznim brašnom i olumom. ${ }^{24}$ U Krivom Putu, Stanić Brigu i Mrzlom Dolu umjesto oluma, za strojenje, koristili su sol i kukuruzno brašno. ${ }^{25}$

Od tako obrađene kože izrađivali su kožune (kožni ogrtač) i šubare (pokrivalo za glavu od kože). ${ }^{26}$

\section{3. ŽENSKA ODJEĆA}

$\check{Z}$ enska odjeća u selima ovog područja sastojala se od donje košulje i podsuknje za koju je zabilježen naziv vriz (Matići, Krivi Put, Katići, Pavelići, Veljun). Preko toga žene su nosile haljinu za koju su zabilježeni nazivi flajda, alja. Umjesto haljine mogla se nositi i suknja, vriz (Matići, Pavići), fuštan (Matići), kiklja (Lucići, Mrzli Dol). Preko suknje ili haljine nosile su pregaču, zaslon ili vriz (Krivi Put, Mrzli Dol). Za zimu su žene plele maje, džempere s rukavima ili bušte, džempere bez rukava, a preko ramena zimi bi prebacile plet, kvadratnu maramu. Čarape (sl. 10) su mogle biti kratke, do gležnja, sokne, suknje (Mrzli Dol) ili soknje (Pavelići). Za čarape visine do koljena ili nešto ispod koljena zabilježeni su nazivi potkoljenke ili potkolenke (Krivi Put, Lucići, Pavelići, Veljun), te dokoljenke ili dokolenke (Krivi Put, Rusova Draga, Stanić Brig, Mrzli Dol, Pavići). Zabilježena je uporaba i čarapa koje su sezale preko koljena, a nazivali su ih podjednako i čarape i duge čarape. ${ }^{27}$

U Upitnici nije precizirano na koje se razdoblje odnosi.

19 Isto.

20 UEA, III, 91, Fd 241/651.

21 Mara Tomljanović Isanova, Krivi Put.

22 Iako je na terenu potvrđeno da je na području Krivog Puta bilo uobičajeno sirovinu za tkanje nositi u Liku, u Upitnici se navodi kako su tare izrađivali ljudi iz sela, te da je svaka kuća imala taru (UEA, III, 92, Fd 241/651). Valjanje je dorađivanje vunenog tkanja pomoću mlaza vode, kako bi tkanje postalo gušće i čvrsto. (Eckhel 1988:39)

24 Kazivači su rekli kako je olum vrsta kamena.

25 Postupak štavljenja kože kazivači mi nisu znali detaljnije opisati.

26 U UEA, za Krivi Put nema podataka o prerađivanju i obradi kože i krzna, tj. navodi se kako se na ovom području te sirovine nisu obrađivale. (UEA, II, 81, Fd 241/651)

27 Podaci iz UEA potvrđuju košulju kao dio donje odjeće, te suknju kao dio osnovne odjeće za koju u Upitnici nije zabilježen lokalni naziv. Podaci potvrđuju i vriz, kao podsuknju, koji je u Upitnici opisan kao haljina bez rukava. Kazivači na terenu nisu mi spomenuli župicu (prsluk), te rubac (marama) koju su žene nosile na glavi. (UEA, II, 78, Fd 241/610) 


\subsection{DONJA ODJEĆA}

\section{Ž} enska donja košulja bila je sašivena od lanenog, konopljinog ili kupovnog platna. ${ }^{28}$ Sezala je do ruba haljine. Donji dio košulje, krilo, bio je izrađen od grubog domaćeg platna jer se nije vidio ispod gornje odjeće. Gornji dio košulje, oplećak, dio je košulje koji se uz gornju odjeću vidi, te je bio izrađen od tvorničkog bijelog platna, koje je finije od domaćeg. ${ }^{29}$ Donja košulja s kratkim ili dugim rukavima predstavljala je češću varijantu u selima na području Krivoga Puta ${ }^{30}$, dok je varijanta donje košulje $s$ naramenicama potvrđena samo u selima Krivi Put i Stanić Brig ${ }^{31}$. Svečanije košulje su na donjem rubu mogle biti ukrašene štikanjem (vezom) ili kupovnom čipkom koja je izvirivala ispod haljine. U selima Krivi Put, Stanić Brig, Katići i Škopci donja košulja sezala je do ispod koljena, nije se nazirala ispod haljine, te nije imala dekoraciju. ${ }^{32}$

Preko kraćih košulja, do koljena, nosila se podsuknja, vriz. Mogla je biti izrađena od lanenog platna ili od kupovnog materijala. ${ }^{33}$ Podsuknja je na završnom rubu bila ukrašena čipkom koja se vidjela ispod suknje. U visini koljena i bokova vriz je imao po jedan horizontalni nabor kao ukras koji su u Krivom Putu nazivali rapica ${ }^{34}$ ili tajičica $^{35}$, a u Lucićima kiklja ${ }^{36}$. U Krivom Putu vriz koji se nosio svakodnevno nazivao se šari vriz i bio je sašiven od kupovnog materijala ${ }^{37}$. Svečani vriz, za kojeg nije zabilježen poseban naziv, bio je sašiven od bijeloga platna. ${ }^{38}$ Treba reći da je podsuknja, kao i naziv za nju (vriz), poznata na cijelom području Krivoga Puta i vjerojatno se ranije nosila uz obje varijante donje košulje.

28 Podaci iz Upitnice potvrđuju da su donji dijelovi odjeće izrađivani od domaćeg konopljinog ili lanenog platna i da su bili bijele boje. (UEA, II, 78, Fd 241/610)

29 Prema podacima iz UEA ispod košulje ponekad se nosio jelek, kraća košulja s rukavima koja je imala funkciju današnjeg grudnjaka (UEA, II, 78, Fd 241/610)

30 Nada Prpić Terezina, Serdari/ Krivi Put; Mira Tomljanović Ropetina, Krivi Put; Josip Prpić Jurina, Stanić Brig; Mile Prpić Popić, Mrzli Dol; Ivanka Krmpotić Šimunova, Škopci; Francika Šojat Babić, Mokina, Šojatski Dolac; Marko Tomljanović Zekan, Matići; Anka Tomljanović Zekanova, Špalji/Matići; Dragica Tomljanović, Podbilo/Matići.

31 Mara Tomljanović Isanova, Veljun/Krivi Put; Josip Prpić Jurina, Stanić Brig.

32 Podaci potvrđeni i u UEA, gdje se navodi da je ženska košulja bila izrađena poput muške, ali je imala ovratnik. U kroju se sastojala od leđa, prsa, rukava $i$ žabice, pod pazuhom (UEA, II, 78, Fd 241/610).

33 Podaci potvrđeni i u UEA gdje se navodi da je vriz dugačak kao i donja košulja, do ispod koljena, te da se preko vriza nosila suknja koja je bila nešto duža od njega i donje košulje (UEA, II, 78, Fd 241/610).

34 Mara Tomljanović Isanova, Krivi Put.

35 Nada Prpić Terezina, Serdari/Krivi Put.

36 Mara Tomljanović Isanova, Krivi Put.

37 Ista kazivačica.

38 Ista kazivačica. 


\subsection{GORNJA ODJEĆA}

Dreko donje košulje žene su nosile haljinu ili suknju. Haljina je bila sašivena od kupovnog materijala 1 koji su žene nabavljale u dućanima u Senju. ${ }^{39}$ Kupovale su materijal tamnije boje s različitim, relativno sitnim uzorcima, najčešće cvjetnim. Haljine su bile sa ili bez rukava, te s kopčanjem na prednjoj strani. ${ }^{40}$

Osim haljina, žene su nosile dugačke suknje koje su mogle biti sašivene od kupovnog materijala, robe, ili od domaćeg vunenog tkanja. ${ }^{41}$ Za široke namreskane (namreškane) suknje, od kupovnog materijala, u Matićima je zabilježen naziv fuštan ${ }^{42}$, a u Lucićima kiklja ${ }^{43}$. U Mrzlom Dolu naziv kiklja koristio se za suknju izrađenu od lana i konoplje. ${ }^{44}$ Sjećanje na varijantu pletene uže suknje zabilježeno je u Matićima, a za takve suknje koristio se naziv vriz ${ }^{45}$, dok se u Pavićima isti naziv koristio općenito za suknje ${ }^{46}$.

I haljine i suknje šivale su priučene seoske šnajderice ${ }^{47}$ koje su se time povremeno bavile.

Preko haljina i suknji žene su nosile zaslon, pregaču od kupovnog materijala koji je za djevojke i mlađe žene bio svjetlije, a kod starijih žena tamnije boje. Pregača je bila dužine do koljena i imala je jedan ili dva džepa. U selima Stanić Brig i Rusova Draga za pregaču je zabilježen naziv vriz. ${ }^{48}$

Zimi žene nisu nosile kaput, nego pletene maje od domaće vune. Naziv maje, na području Krivoga Puta, zabilježen je za pletene džempere s rukavima, koji su najčešće bili neukrašeni. Ženske džempere bez rukava nazivali su bušti i bili su, kao i maje, većinom neukrašeni. U Mrzlom Dolu žene su ponekad vezle cvijet na prsima u drugoj boji i to najčešće s live strane di je srce, kao ljubav, kao da će imat momka, da će se zaljubiti. ${ }^{49}$

I bušti i maje mogli su biti zatvoreni ili na kopčanje. U većini slučajeva nije bila bitna boja vune kojom su izrađeni maje i bušti, te se na području Krivog Puta najčešće koristilo vunu crne i bijele boje. ${ }^{50}$ Maje i bušti bili su minimalno ukrašeni i to jednostavnim motivima, poput pletenice, izrađenim drugim bodom, zatim priduplanim (porubljenim) rubom ili su mogli imati opletenu striku (prugu), u drugoj boji, na rubovima. Ženske maje i bušti imale su vratni izrez u obliku slova V i to je bila njihova osnovna razlika u odnosu na muške maje i pulovere. ${ }^{51}$

Na području Krivoga Puta nema sjećanja da je kanica, pojas, bila sastavni dio ženske nošnje, ni kao estetski ni kao funkcionalni element. ${ }^{52}$

39 O dućanima raznolikom robom, koje su u Senju otvarali mahom povratnici s rada u Americi, pogledaj više u prilozima Marijete Rajković o migracijama, str. 83., te Tihane Rubić o trgovinskim aktivnostima, str. 347., u prvom svesku ove monografije.

40 U selima Krivoga Puta nije zabilježen poseban naziv za takve haljine.

41 Podaci iz Upitnice potvrđuju da se za izradu suknje koristilo domaće ili kupovno sukno ili tkanine, te da ukoliko je riječ o kupovnom materijalu bio je najčešće bijele, crvene ili modre boje, te crne za starije žene. (UEA, II, 78, Fd 241/ 610).

42 Anka Tomljanović Zekanova, Matići; Dragica Tomljanović, Matići.

43 Marija Prpić Kavarica, Lucići.

44 Mile Prpić Popić, Mrzli Dol.

45 Marko Tomljanović Zekan, Matići; Anka Tomljanović Zekanova, Matići; Dragica Tomljanović, Matići

46 Zdenka Pavelić, Pavići.

47 Od njemačkog schneider što znači krojač (Klaić 1986:1300).

48 Josip Blažević Ivela, Stanić Brig; Marko Prpić Rus, Rusova Draga.

49 Mile Prpić Popić, Mrzli Dol.

50 Mira Tomljanović Ropetina, Krivi Put; Stjepan Šojat Mokin, Provoz; Ruža Šojat Mokina, Provoz; Marija Prpić Vinina, Veljun; Pavla Pavelić Ćirilova, Pavelići.

51 Prema podacima iz UEA žene su nosile župicu, prsluk s rukavima i kopčanjem s prednje strane. Nije navedeno od kojeg materijala i kojom tehnikom je župica izrađena (UEA, II, 78-79, Fd 241/610)

52 Na čitavom istraživanom području senjskog zaleđa, uključujući i područje Senjskoga bila, kanicu je spomenula jedino kazivačica Đura Biondić iz Liskovca koja se sjeća da su je u Liskovcu još iza Drugoga svjetskog rata nosile tri starije žene, a sve tri su rodom bile iz Senjske Drage. Podaci iz Upitnice navode da su pojaseve nosili i muškarci i žene. 
Žene su zimi nosile plet, pletenu kvadratnu maramu koju su prebacivale preko glave i leđa te prekrižile na prsima. ${ }^{53}$

Kosu su žene uređivale jednostavno. Kao djevojčice i djevojke, kosu su plele u jednu ili dvije pletenice, a kao žene u jednu pletenicu koju uviju u kolo zad glave $e^{54}$. Tako počešljane žene povezivale su rubac. Rubac je bio od kupovne tkanine, četverokutnog oblika, a slagao se u trokut i vezao pod bradom ili na tjemenu. Djevojke su nosile rubce svjetlijih boja, s raznim šarama. Što su bile starije, djevojke i žene, nosile su rubce tamnijih boja. Oglavlje je dakle bilo relativno jednostavno, te nije posebno označavalo različite faze u životu žene. ${ }^{55}$

\section{3. ČARAPE}

$\checkmark$ ene su za zimu plele čarape od vune, koje su mogle biti kratke, do koljena, ili preko koljena. Kratke čarape nazivali su sokne, osim u Mrzlom Dolu gdje je potvrđen naziv suknje ${ }^{56}$.

Čarape do koljena u selima Krivi Put, Lucići, Pavelići i Veljun nazivali su potkoljenke ili potkolenke. ${ }^{57}$ Nadalje, u Krivom Putu, Rusovoj Dragi, Stanić Brigu i Pavićima takve su čarape nazivali dokoljenke ili dokolenke. ${ }^{5}$ One su na vrhu mogle imati provučenu trakicu s kitama na krajevima i to je u većini slučajeva predstavljalo njihovu svečaniju inačicu.

Žene su plele i čarape do iznad koljena koje su na vrhu imale provučenu gumu, a bile su namjenjene uglavnom starijim ženama. ${ }^{59}$ Nazivali su ih jednostavno čarape $e^{60} \mathrm{ili}$ duge čarape ${ }^{61}$.

U Rusovoj Dragi, Pavelićima, Stanić Brigu, Gorici i Škopacima ženske čarape bile su pletene od bijele vune. ${ }^{62}$ U Provozu, Pavićima, Pavelićima, Krivom Putu, Veljunu, Katićima, Mrzlom Dolu i Gorici izrađivali su čarape od vune, sive ili crne boje, koje su uglavnom bile namijenjene starijim ljudima kao radna varijanta čarapa iz jednostavnog razloga što se čarape tamne boje manje prljaju. ${ }^{63}$

Muškarci su nosili kožne pojaseve, kajševe. Prema podacima iz te upitnice kazivač je čuo da su preko kaiša muškarci nosili drugi kožni pojas ćemer, ali to nije vidio. U Upitnici se ne navodi da li se taj podatak odnosi na muškarce s ovog područja. U istoj upitnici navodi se da su žene nosile tkani pojas, kanicu. Kanica je bila malo duža od širine struka, mogla je biti jednobojna ili tkana u nekoliko boja, otkana u širini tri prsta. Takav pojas je na krajevima završavao resama i vezao se s prednje strane. Za pojas su muškarci zaticali pribor za duhan, a žene rupčić. (UEA, III, 80, Fd 241/651)

53 Marija Prpić Vinina, Veljun; Mara Tomljanović Isanova, Krivi Put.

$54 \mathrm{Na}$ terenu je propušteno ispitivanje teme oglavlja. Podaci su preuzeti iz UEA u kojoj se opisuje uređenje kose i oglavlje kroz različitu životnu dob: Male curice već počinju plesti jednu ili dvije pletenice, a takoder i cure. Nevjesta kao i druge cure. Žena uvije pletenicu u kolo kod glave. Učvrste s gabrlama. Kazivač: Milan Krmpotić, ispitivač: Slobodan Šimić, ispitivano: šezdesetih godina 20. stoljeća. (UEA, III, 83, Fd 241/651)

55 Kazivači tijekom ispitivanja teme odijevanja nisu isticali razlike u odijevanju i oglavlju žene tijekom života. Prema podacima iz UEA razlikovali su se načini vezanja rubca za mlađe i starije žene, te za rad u polju. Razlika u odijevanju bila je očigledna napose u boji odjeće: starije su žene nosile gornju odjeću tamnije boje, kao i žene u žalosti koje su nosile odjeću crne boje (UEA, III, 83, Fd 241/651).

56 Mile Prpić Popić, Mrzli Dol.

57 Marija Prpić Kavaričina, Lucići; Nada Prpić Terezina, Krivi Put; Anka Pavelić Kuzmanova, Pavelić; Marija Prpić Vinina, Veljun.

58 Mira Tomljanović Ropetina, Krivi Put; Marko Prpić Rus, Rusova Draga; Josip Prpić Jurina i Milka Prpić, Stanić Brig; Ika Pavelić Tomina, Pavići.

59 Prema kazivanju Mile Prpića Popića i Ivanke Krmpotić Šimunove takve čarape nisu bile poznate u Mrzlom Dolu i Škopcima.

60 Ika Pavelić Tomina, Pavići; Nada Prpić Terezina, Krivi Put; Mira Tomljanović Ropetina, Krivi Put.

${ }_{61}$ Anka Pavelić Kuzmanova, Pavelići; Marko Prpić Rus, Rusova Draga; Marija Prpić Kavaričina, Lucići; Ljubica Prpić, Lucići; Mara Tomljanović Isanova, Krivi Put.

62 Ivanka Krmpotić Šmunova, Škopci; Marko Prpić Rus, Rusova Draga; Anka Pavelić Kuzmanova, Pavelići; Grgo i Ljubica Prpić Miškecova, Anka Prpić Stipina, Gorica; Josip Prpić Jurina, Stanić Brig; Josip Blažević Ivela, Stanić Brig; Milan Blažević Nikolin, Stanić Brig.

63 Mile Prpić Popić, Mrzli Dol; Marko i Draga Tomljanović Rilčeva, Katići; Nada Prpić Terezina, Krivi Put; Anka Pavelić Kuzmanova, Pavelići; Ruža Šojat Mokina, Provoz; Marija Prpić Vinina, Veljun; Mile Pavelić Vranićov, Pavići; Grgo 
Muške i ženske čarape razlikovale su se po veličini i bodu, odnosno načinu pletenja. Ženske čarape plele su se tako da im je stopalo glat ${ }^{64}$ (opleteno kombiniranjem jedne prave i jedne krive očice), a od zgloba do kraja čarape kombinirale su se dvije ili više pravih očica s isto toliko krivih očica. ${ }^{65}$

\section{MUŠKA ODJEĆA}

$\mathrm{M}$ uška odjeća sastojala se od svitica, donjih gaća preko kojih su se nosile hlače od kupovnog materijala, rajtoze ili rajt hlače, te košulje. Kaput, ćurak, bio je dužine do bokova, a zabilježena je pojava i dužeg kaputa, kobanice (Matići, Mrzli Dol) ${ }^{66}$ Ispod kaputa nosio se prsluk, ćerma. ${ }^{67}$ Za zimu su žene muškarcima plele maje, džempere s rukavima; pulovere, džempere bez rukava, te čarape. Plele su također i odjevni predmet, poput nogavica, koji se nosio preko hlača, a sezao je od gležnja do koljena, a za koji su zabilježeni nazivi natikače (Lucići) ${ }^{68}$, strimfe (Krivi Put, Katići, Matići, Šojatski Dolac, Stanić Brig, Mrzli Dol) ${ }^{69}$, nakoljenice (Škopci) ${ }^{70}$, te štumfarice $(\text { Veljun })^{71}$. Odjevni predmet sličan prethodnome, ali za ruke, nazivali su zašaknjače (Krivi Put, Lucići, Matići, Mrzli Dol, Pavići, Veljun) ${ }^{72}$ ili narukvice (Gorica) ${ }^{73}$. Na gotovo cijelom ovom području, od kože su izrađivani kožuni i šubare. Jedino u selima Lucići, Veljun i Škopci nije zabilježena uporaba kožuna. ${ }^{74}$

\subsection{DONJA ODJEĆA}

Sitice, muške donje gaće, bile su izrađivane od lanenog ili konopljinog platna, buštana (flanela) ili Kupovnog materijala, a u struku su se stezale uvlavčnjakom ili svitnjakom (trakicom provučenom u pojasu). ${ }^{75}$ Naziv svitice koristi se i danas na području Krivoga Puta, a odnosi se na duge muške gaće općenito. Gaće su bile duge do gležnja, a nogavice su bile izrađene od jedne pole platna. ${ }^{76}$ Kao gornja

i Ljubica Prpić Miškec, Anka Prpić Stipina, Gorica. Prema podacima UEA ženske čarape su bile crne, a muške bijele boje. (UEA, III, 85, Fd 241/651)

${ }^{64}$ Od njemačkog glatt što znači gladak, ravan, bez nabora (Klaić 1986:487).

65 Pavla Pavelić Cirilova, Pavelići; Draga Tomljanović Rilčeva, Katići. Podaci o ovoj temi u Upitnici su dosta šturi, te govore općenito o čarapama, a samo u navedenom podatku o boji razlikuju muške i ženske čarape. (UEA, III, 85, Fd 241/651).

66 Mile Prpić Popić, Mrzli Dol; Ivan Tonković, Matići

67 Marko Tomljanović Zekan, Matići; Ivan Tonković, Matići; Josip Blažević Ivela, Stanić Brig; Milan Blažević Nikolin, Stanić Brig; Mara Tomljanović Isanova, Veljun/Krivi Put.

68 Marija Prpić Kavaričina, Lucići; Ivan Prpić Kavarica, Lucići.

69 Mara Tomljanović Isanova, Krivi Put; Nada Prpić Terezina, Krivi Put; Marko Tomljanović Rilac, Katići; Marko Tomljanović Zekan, Matići; Dragica Tomljanović, Matići; Francika Šojat Babić, Mokina, Šojatski Dolac; Josip Blažević Ivela, Stanić Brig; Josip Prpić Jurina, Stanić Brig; Mile Prpić Popić, Mrzli Dol, Dubravka Prpić, Mrzli Dol.

$70 \quad$ Ivanka Krmpotić Šimunova, Škopci; Pavla Pavelić Ćirilova, Veljun.

71 Marija Prpić Vinina, Veljun.

72 Marko Tomljanović Zekan, Matići; Anka Tomljanović Zekan, Matići; Ružica Tonković Mukinova, Matići; Mile Pavelić Vranićov, Pavići; Pavla Pavelić Ćirilova, Veljun; Marija Prpić Kavaričina, Lucići; Ljubica Prpić, Lucići; Mile Prpić Popić, Mrzli Dol; Nada Prpić Terezina, Krivi Put.

73 Anka Prpić Stipina, Gorica.

74 Marija Prpić Vinina, Veljun; Marija Prpić Kavaričina, Lucići; Ivan Prpić Kavarica, Lucići; Ivanka Krmpotić Šimunova, Škopci.

75 Ivanka Krmpotić Šimunova, Škopci; Pavla Pavelić Ćirilova, Pavelići; Zdenka Pavelić, Pavići; Marko Tomljanović Zekan, Ivan Tonković, Anka Tomljanović Zekanova, Dragica Tomljanović, Matići; Mile Prpić Popić, Mrzli Dol; Marko Tomljanović Rilac, Katići; Mara Tomljanović Isanova, Krivi Put; Neda Prpić Terzina, Krivi Put.

76 Potvrđuju i podaci iz UEA (UEA, II, 77, Fd 241/610). 
odjeća, gaće su se nosile do početka 20. stoljeća, nakon čega su se češće počele nositi hlače od kupovnih, industrijskih materijala.

Ljeti i zimi muškarci su nosili košulju bijele boje izrađenu od lanenog i konopljinog platna. ${ }^{77}$

\subsection{GORNJA ODJEĆA}

$\mathrm{M}$ uške hlače, rajtoze ili rajt hlače ${ }^{78}$, izgledom su podsjećale na oficirske, vojničke hlače, jer su u struku bile široke, a od koljena na dolje, uske. Rajtoze najčešće nisu imale dekorativnih elemenata, bile su izrađene od kupovnog materijala, no u Matićima, Krivome Putu, Rusovoj Dragi, Katićima i Veljunu sjećaju se i starije varijante hlača šivanih od tkane vune. ${ }^{79} \mathrm{U}$ Veljunu su takve hlače od tkane vune izrađivali za ljude koji su kirijali (izvlačili drva iz šume). Hlače su u Mrzlom Dolu izrađivali od tkanog lana i konoplje jer najviše se radilo za moču od konoplje, od lana...za hladnoću i kad je vlažno vrime... a vuna ovčja ona više pušta vodu. ${ }^{80}$

Na području Krivoga Puta muškarci su zimi nosili kraći kaput, dužine do bokova, koji su nazivali ćurak. ${ }^{81}$ Taj izraz ljudi koriste i danas za svaki kraći kaput ili gornji dio muškog odijela. Curak je bio izrađen od tkane vune ili od lana i konoplje. Uglavnom je bio siv ili crn, te nije bio ukrašavan. U Matićima i Mrzlom Dolu potvrđena je i uporaba kobanica, dugačkih kaputa od vune ili štofa. ${ }^{82}$

U svim selima ovog područja ispod ćurka muškarci su nosili ćermu, prsluk, koji je bio sašiven od istog materijala kao ćurak i nije bio ukrašavan. ${ }^{83}$ Naziv ćerma ljudi su zadržali i danas, te tako nazivaju prsluk koji je sastavni dio kupovnog muškog odijela.

Vunu za izradu hlača, ćurka i ćerme nosili su tkati u Liku ili su te odjevne predmete kupovali kao gotove proizvode u Lici. ${ }^{84}$

Muškarci su nosili pletene džempere bez rukava koje su nazivali puloveri, te džempere s rukavima koje su nazivali maje. ${ }^{85}$ I puloveri i maje bili su zatvoreni ili na kopčanje. Najčešće nisu bili posebno ukrašavani, a najjednostavnije varijacije ukrasa postizane su kombiniranjem različitih bodova, priduplanim rubovima ili oplitanjem rubova strikom u boji. Razlika između muških i ženskih maja najviše se vidjela u njihovoj veličini, te obliku vratnog izreza. Naime, muške maje i puloveri imali su izrez u srce (polukružan). ${ }^{86}$

Podaci iz UEA donose detaljniji opis košulje koja je bila krojena od dva jednaka komada platna koja su spojena na ramenima. Ispod pazuha se ušivao komad tkanine koji su nazivali žabica. Ovakva košulja nije imala ovratnik, a rukavi su bili dugi do zapešća i tu stisnuti. Na prsima, uz raspor, bila je ukrašena vezom. Muškarci su je nosili umetnutu u svitice (UEA, II, 76, Fd 241/610).

78 Od njemačkog reithose što znači hlače za jahanje, ozgo široke, a uz koljena i listove usko priljubljene. (Klaić 1986:1129).

79 Prilikom terenskog istraživanja nisu prikupljeni podaci o tome tko je izrađivao pojedine odjevne predmete, a podaci iz UEA navode kako su i gaće i hlače izrađivale žene. Upitnica donosi i detaljan opis hlača koje su sezale do gležnja, ravno krojenih nogavica, bez dodatno krojenih umetaka, sa šavom na vanjskoj strani. S prednje strane imale su raspor, $u$ struku su se stezale uzicom, svitnjakom, a sa strane u visini bokova imale su po jedan koso rezan džep (UEA, II, 77, Fd $241 / 610)$

80 Mile Prpić Popić, Mrzli Dol.

81 Pavla Pavelić Ćirilova, Pavelići; Anka Pavelić Kuzmanova, Pavelići; Josip Blažević Ivela, Stanić Brig; Milan Blažević Nikolin, Stanić Brig; Josip Prpić Jurina, Stanić Brig; Francika Šojat Babić, Mokina, Šojatski Dolac; Mara Tomljanović Isanova, Krivi Put.

82 Mile Prpić Popić, Mrzli Dol; Ivan Tonković, Matići.

83 Josip Blažević Ivela, Stanić Brig; Milan Blažević Nikolin, Stanić Brig; Mara Tomljanović Isanova, Krivi Put; Marko Tomljanović Zekan, Matići; Ivan Tonković, Matići.

84 Francika Šojat Babić, Mokina, Šojatski Dolac; Ivan Tonković, Matići.

85 Ivanka Krmpotić Šimunova, Škopci; Marija Prpić Kavaričina, Ivan Prpić Kavarica, Ljubica Prpić, Lucići; Marija Prpić Vinina, Veljun; Stjepan i Ruža Šojat Mokini, Provoz; Ika Pavelić Tomini, Pavići; Grgo i Ljubica Prpić Miškec, Gorica; Anka Prpić Stipina, Gorica; Josip Blažević Ivela, Stanić Brig; Milan Blažević Nikolin, Stanić Brig; Josip i Milka Prpić Jurini, Stanić Brig; Nada Prpić Terezina, Krivi Put; Mira Tomljanović Ropetina, Krivi Put.

86 Stjepan i Ruža Šojat Mokini, Provoz; Ika Pavelić Tomini, Pavići; Grgo i Ljubica Prpić Miškec, Stjepan i Anka Prpić Stipini, Gorica. 
U većini mjesta nije bila bitna boja vune kojom su se pleli, pa ipak, u selima Krivi Put, Gorica, Veljun i Škopci muške maje žene su plele većinom od bijele vune. ${ }^{87}$

Za zimu, žene su muškrcima plele manice. Manice su pletivo poput rukava koje se navlačilo na ruku preko maje, a sezale su od šake do lakta. Naziv manice upotrebljavao se u Matićima i Krivom Putu gdje se uz ovaj koristio i naziv zašaknjače kao i u Mrzlom Dolu, Lucićima, Pavićima i Veljunu ${ }^{88}$, dok se u Gorici isti predmet nazivao narukvice ${ }^{89}$. Manice, zašaknjače, narukvice najčešće su bile izrađene od jednobojne vune, ali su mogle biti ukrašene strikama u boji.

\section{3. ČARAPE}

$\mathrm{N}$

a čitavom području Krivoga Puta muškarci su nosili čarapa do koljena, a jedino u Pavićima i Škopcima čarape su bile pletene do pola lista. ${ }^{90}$ Muške čarape pretežno su se izrađivale od bijele vune, a razlika između muških i ženskih čarapa bila je u veličini i bodu. Tako su muške čarape imale pravim očicama opleteno stopalo i desetak centimetara od zgloba noge naviše, a dalje, do vrha čarape kombinirane su dvije krive dvije prave očice.

Zimi su muškarci nosili opleten odjevni predmet poput nogavice koji se nosio preko hlača, a sezao je od gležnja do koljena ili preko koljena. U većini sela na području Krivoga Puta nazivali su ga štrimfe. ${ }^{91} \mathrm{Za}$ isti predmet u Lucićima potvrđen je i naziv natikače ${ }^{92}$, a u Škopcima nakoljenice ${ }^{93}$. U Veljunu je jedna od lokalnih varijanta naziva štumfarice ${ }^{94}$.

U selima na području Krivogaa Puta štrimfe su bile jednobojne, a pri vrhu su mogle imati upletenu striku, te su se znale privratiti (podvrnuti) ako su bile opletene preko koljena. Namjena śtrimfi, odnosno natikača, bila je zaštita od prodiranja snijega pod nogavicu.

\subsection{KOŽNI ODJEVNI PREDMETI}

d obrađenih ovčjih koža seoske šnajderice šile su kožune, krznene ogrtače, koji su sezali do bedara, odnosno do iznad koljena, a dužih kožuna sjećaju se jedino u Pavelićima ${ }^{95}$. U selima Lucići, Serdari, Stanić Brig, Gorica, Provoz, Veljun i Škopci ljudi se danas više ne sjećju kožuna kao odjevnog predmeta. ${ }^{96}$

U većini sela na području Krivoga Puta vuna je bila okrenuta prema tijelu, a u Mrzlom Dolu, Pavićima i Pavelićima kožun se mogao nositi obostrano, zavisno od vremenskih prilika. Naime, za hladna i vjetrovita

87 Mira Tomljanović Ropetina, Krivi Put; Ivanka Krmpotić Šimunova, Škopci; Marija Prpić Vinina, Veljun; Ljubica Prpić Miškecova, Gorica.

88 Marko Tomljanović Zekan, Matići; Anka Tomljanović Zekan, Matići; Ružica Tonković Mukinova, Matići; Mile Pavelić Vranićov, Pavići; Pavla Pavelić Cirilova, Veljun; Marija Prpić Kavarica, Lucići; Ljubica Prpić, Lucići; Mile Prpić Popić, Mrzli Dol; Nada Prpić Terezina, Krivi Put.

89 Anka Prpić Stipina, Gorica.

90 Ivanka Krmpotić Šimunova, Škopci; Ika Pavelić Tomina, Pavići.

${ }_{91}$ Štrimfa, u rječniku B. Klaića štrimfla prevedena s njemačkog strumpf znači čarapa, bječva (Klaić 1986:1312). Ovaj naziv potvrdili su kazivači: Mara Tomljanović Isanova, Krivi Put; Nada Prpić Terezina, Krivi Put; Marko Tomljanović Rilac, Katići; Marko Tomljanović Zekan, Matići; Dragica Tomljanović, Matići; Francika Šojat Babić, Mokina, Šojatski Dolac; Josip Blažević Ivela, Stanić Brig; Josip Prpić Jurina, Stanić Brig; Mile Prpić Popić, Mrzli Dol; Dubravka Prpić, Mrzli Dol; Ivanka Krmpotić Šimunova, Škopci; Pavla Pavelić Cirilova, Veljun.

92 Marija Prpić Kavarica, Lucići; Ivan Prpić Kavarica, Lucićí.

93 Ivanka Krmpotić Šimunova, Škopci; Pavla Pavelić Ćirilova, Veljun.

94 Štumfarice u rječniku B. Klaića štrumfa, štumfa prevedena s njemačkog strumpf znači čarapa, bječva (ibid.). Ovu varijantu naziva potvrdila je Marija Prpić Vinina, Veljun.

95 Pavla Pavelić Ćirilova, Pavelići.

96 Marija Prpić Vinina, Veljun; Marija Prpić Kavaričina, Lucići; Ivan Prpić Kavarica, Lucići; Ivanka Krmpotić Šimunova, Škopci; Josip Blažević Ivela, Stanić Brig; Milan Blažević Nikolin, Stanić Brig; Grgo i Ljubica Prpić Miškec, Stjepan i Anka Prpić Stipini, Gorica; Stjepan Šojat Mokin, Provoz. 
vremena vuna se nosila okrenuta prema tijelu, radi topline. Za kišnih dana vuna se okretala prema van da se koža ne bi smočila, te da se voda slijeva niz dlake. ${ }^{97}$

Vuna na kožunu bila je kraća, dužine svega jedan do dva centimetra, a jedino je u Matićima i Katićima bila duža ${ }^{98}$. U Mrzlom Dolu i Stanić Brigu bila je istovjetne dužine kao na ovci. ${ }^{99}$ Kožuni su se u većini sela ovoga područja izrađivali bez rukava. U selima Matići i Mrzli Dol izrađivani su i kožuni s rukavima. ${ }^{100}$ Kožuni su većinom bili izrađeni od vune bijele boje. Samo u Krivom Putu vuna na kožunu bila je crne boje. $^{101}$

U većini sela na području Krivoga Puta nosile su se šubare, ali ih nisu izrađivali ljudi u tim selima, već su ih kupovali u Lici. ${ }^{102}$ Iznimka su sela Matići, Stanić Brig i Mrzli Dol gdje ih je izrađivao netko u selu. ${ }^{103}$

Dok je šubara bila glavno zimsko pokrivalo za glavu, ljeti su muškarci nosili šešire i razne vrste kapa koje su kupovali u Senju. Crvenkape nisu bile kape svojstvene tradicijskom odijevanju Bunjevaca na ovom području te se javljaju u novije vrijeme ${ }^{104}$.

\section{OBUĆA}

$\mathrm{N}$ a području Krivoga Puta glavnu obuću predstavljale su šlape (sl. 11a, b) i opanci. Šlape su vrsta obuće domaće proizvodnje koja se mogla nositi i zimi i ljeti. Žene su šlape plele od domaće vune, a u Mrzlom Dolu, Krivom Putu i Stanić Brigu izrađivale su ih i od tkane vune, debele i po $2 \mathrm{~cm}$, te su ih i podšivali s tkanom vunom. Ipak, u većini sela šlape su se podšivale ovčjom ili telećom kožom, te u novije vrijeme, iza Drugoga svjetskog rata, gumom. Izbjegavalo se šlape podšivati kožom jer je tad bilo sklisko. Šlape su u pravilu izrađivali od tamnije vune da se manje vidi prljavština.

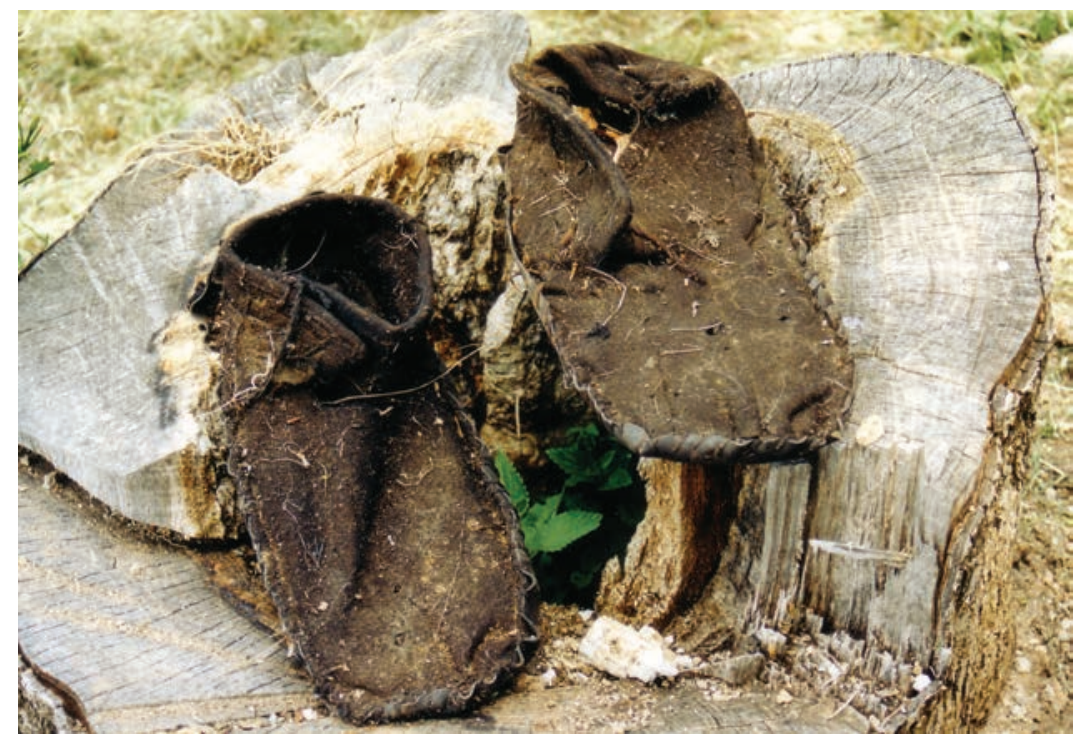

Slika 11, 11a: Šlape od vune, podšivene kơ̌om, vlasnik Milan Tomljanović Ivić, Cupiči; snimio Augustin Perić, lipanj 2003.

97 Josip Prpić Jurina, Stanić Brig; Mara Tomljanović Isanova, Krivi Put; Mile Prpić Popić, Mrzli Dol; Mile Pavelić Vranićov, Pavići; Pavla Pavelić Cirilova, Pavelići.

98 Marko Tomljanović Zekan, Matići; Marko Tomljanović Rilac, Katići.

99 Josip Prpić Jurina, Stanić Brig; Mile Prpić Popić, Mrzli Dol.

100 Mile Prpić Popić, Mrzli Dol; Marko Tomljanović Zekan, Anka Tomljanović Zekan, Dragica Tomljanović, Matići.

101 Mara Tomljanović Isanova, Krivi Put.

102 Mira Tomljanović Ropetina, Krivi Put; Marko Tomljanović Rilac, Katići.

103 Josip Prpić Jurina, Stanić Brig, Mile Prpić Popić, Mrzli Dol; Marko Tomljanović Zekan, Matići.

104 Prema podacima s terena muškarci ih jesu nosili u razdoblju oko Drugoga svjetskoga rata, ali ne i u ranijim razdobljima. Crvenkapu potvrđuje i podatak iz Upitnice (UEA III, 82, Fd 241/651) 


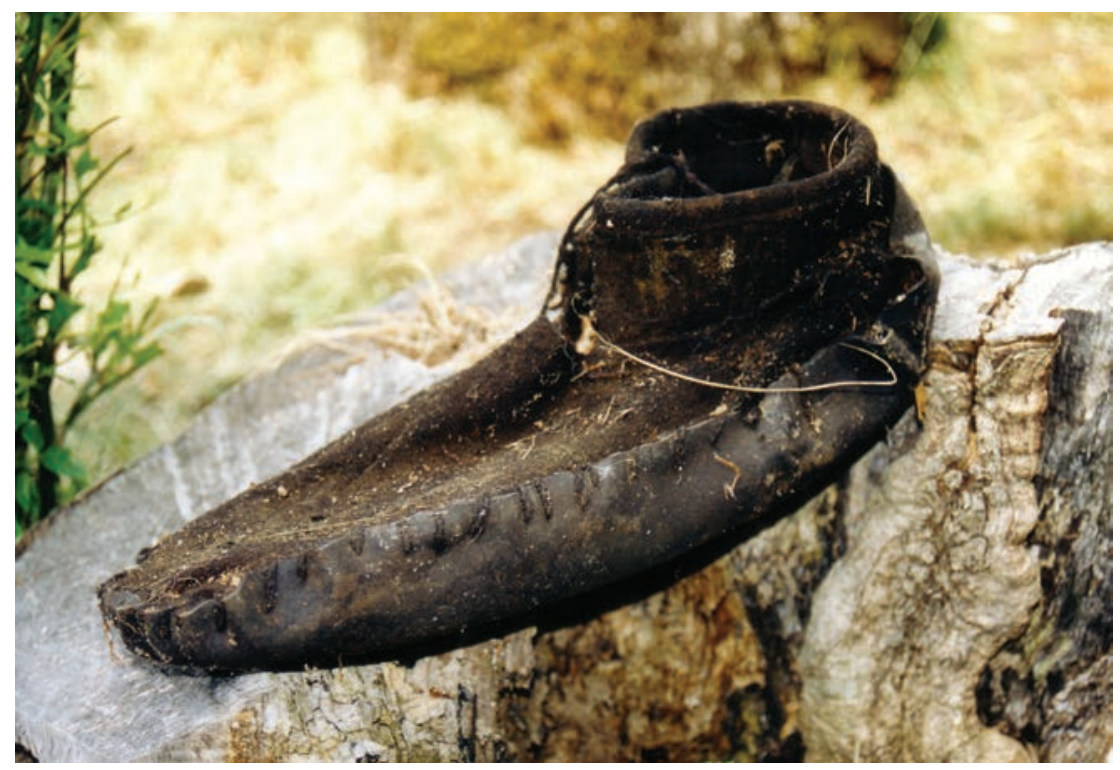

Slika 11 a

Opanke su kupovali u Brinju i Senju ili su ih izrađivali seoski šusteri (postolari) od kravlje kože. ${ }^{105} \mathrm{Ku}-$ povni opanci mogli su biti gumeni ili kožni, te bi tada na gornjem dijelu imali mekšu kožu, a na donjem tvrđu. Mogli su biti izrađeni i kombinacijom kože i gume, a tada bi na gornjem dijelu imali kožu, a na donjem gumu. Bez obzira na materijal većina opanaka imala je brukvice, tj. čavliće na potplatu, kako bi se usporilo trošenje i spriječilo klizanje. U opanke je mogla biti upletena koža druge boje, tj. u crne cipele žuta koža, na žute cipele crna i tako. ${ }^{106}$ Tako ukrašene opanke oblačili bi nedjeljom za odlazak u crkvu. Cipele su nosili imućniji ljudi, a čizme se nisu nosile. ${ }^{107}$

Uz navedenu obuću, ljudi su noge omatali i obojcima koji su bili izrađeni od starih suknenih krpa. ${ }^{108}$

Tijekom ljetnih mjeseci, srpnja i kolovoza, ljudi su po selu hodali bosi, dok su zimi koristili krplje koje su sami izrađivali, a koje su za obuću bile pričvršćene špagom. ${ }^{109}$

\section{TORBE}

$\mathrm{O}_{\mathrm{p}}^{\mathrm{d}}$ $\mathrm{d}$ vune su bile izrađivane i torbe. Ljudi su ih nosili prilikom čuvanja blaga, odlaska na sajam ili na put, a djeca su ih nosila u školu. Torbe su mogle biti pletene i tada su ih izrađivale žene svojim ukućanima. ${ }^{10}$ Tkane torbe češće su bile korištene na ovom području, a bile su otkane i kupovane u Lici. ${ }^{111}$ Torbe s jednom uprticom (naramenicom), na jedno rame, bile su ukrašene kitama smještenim na rubovima. Uz te torbe, izrađivale su se i torbe s naramenicama preko dva ramena, ruksaci, koje su većinom bile jednobojne i jednostavne, osim u Matićima i Krivom Putu gdje su bile ukrašene kitama ${ }^{112}$.

\footnotetext{
105 Tijekom istraživanja ove teme nisu zabilježena imena osoba koje su izrađivale opanke.

106 Marija Prpić Kavaričina, Lucići.

107 Prema podacima u Upitnici Etnološkog atlasa čizme se na području Krivoga Puta nisu nosile, a cipele su nosili samo pojedinci koji su bili na radu u Njemačkoj. (UEA, III, 85, Fd 241/651)

108 U UEA se navodi da su umjesto obojaka ljudi nosili natikače, kratke čarape pletene od vune. (UEA, III, 85, Fd 241/651)

109 Prema podacima iz UEA. (UEA, III, 104, Fd 241/651)

110 Matići, Stanić Brig.

111 Tkane torbe spomenuli su mi kazivači u: Krivome Putu, Katićima, Mrzlom Dolu, Pavićima, Šojatskom Dolcu i Veljunu. Podaci o tkanim torbama za Krivi Put zabilježeni su i u UEA (UEA, III, 84, Fd 241/651).

112 Marko Tomljanović Zekan, Matići; Mara Tomljanović Isanova, Krivi Put; Mira Tomljanović Ropetina, Krivi Put.
} 


\section{UPORABNI TEKSTIL I ŽENSKI RUČNI RAD (ŠTIKANJE, ŠLINGANJE, HEKLANJE)}

\subsection{UPORABNI TEKSTIL}

Tekstilni predmeti poput biljaca (sl. 12), šarenica (sl. 13), i krpara (sl. 14), koji ne pripadaju grupi odjevnih predmeta, već skupini uporabnih tekstilnih predmeta, estetski su dojmljivi i uključeni su u prikaz tradicijskog odijevanja na području Krivoga Puta jer te tekstilne predmete ljudi smatraju izrazitim i specifičnim elementom svoje tradicijske baštine.

Ovdje je potrebno ponoviti da Bunjevke na ovom području nisu tkale, već su vunu, lan i konoplju nosile na tkanje u Liku, osim u iznimnim slučajevima ako bi se Ličanka nakon udaje doselila u neki od ovih lokaliteta $^{113}$. Na području Krivoga Puta vuna je na tkanje nošena u Vratnik, Prokike, Ritavac i Brlog ${ }^{114}$.

Biljac (sl. 12) (pokrivač) je mogao biti kukičasti, bez kita i kićeni, s kitama koje su najčešće formirane u kvadrate različitih boja. Prvotno je biljac služio kao pokrivač, a danas ga ljudi često koriste kao tepih. Za nit osnove u izradi biljaca koristila se najkvalitetnija vuna, dok se za potku mogla koristiti i vuna lošije kvalitete. Biljac su žene tkale $u$ dva reda (od dvije pole tkanja), koja su se spajala jer se širina potrebna za prekrivanje nije mogla odjednom otkati na tari (tkalačkom stanu). ${ }^{115}$ Nakon što se biljac otkao, nosio se valjati na vodu, na Gacku u Švicu. Osim raznobojnih kukičastih biljaca koji su imali rese, od vune su izrađivali i deke bez resa, glatke i jednobojne, crne i bijele.

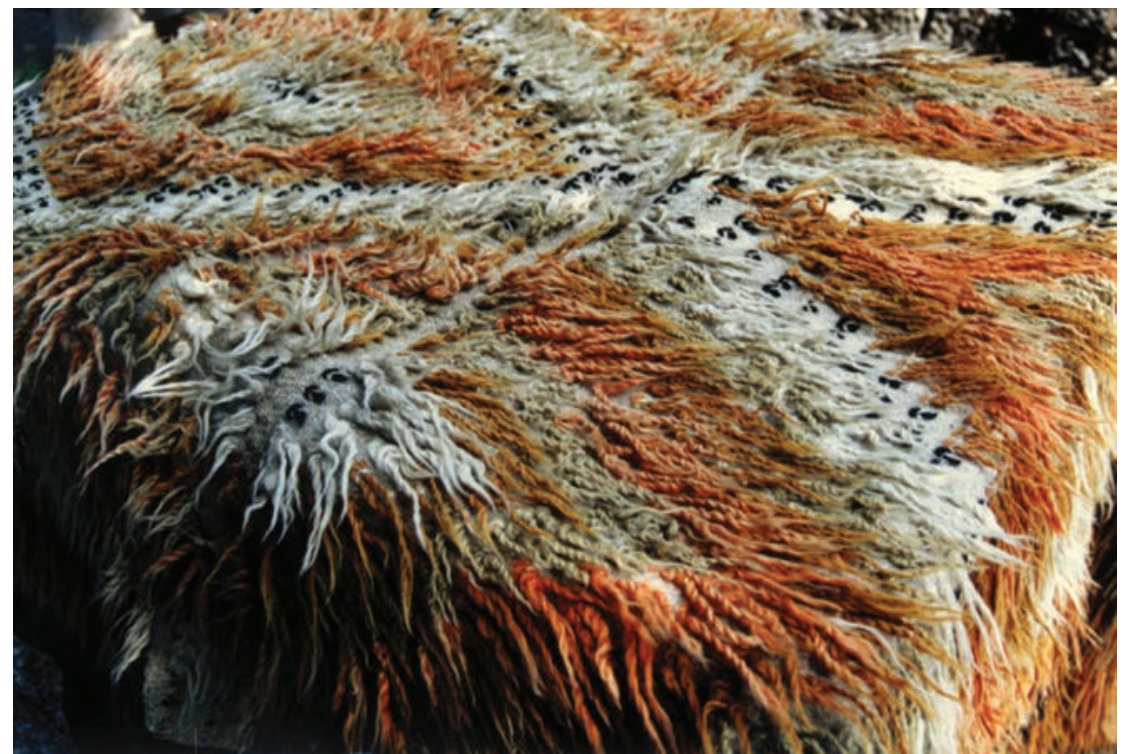

Slike 12: Biljac, vlasnik Milan Tomljanović Ivić, Cupići; snimio Augustin Peric, lipanj 2003.

Šarenice (sl. 13) su tkani vuneni prekrivači za krevet, a mogle su se vješati i na zid. Tropolke su bile šarenice izrađene od tri pole, bez resa na rubovima, te su bile namijenjene za prekrivanje duplih kreveta (bračnih kreveta). Šarenica za prekrivanje jednog kreveta bila je manja i s jedne strane završavala je resama. One za zid mogle su biti duge i po nekoliko metara, a široke oko $60 \mathrm{~cm}$. Najčešći motivi na šarenicama bili su stilizirani cvjetovi ili geometrijski ornament, poput rombova.

\footnotetext{
${ }_{113}$ Više o tome vidi u prilogu o trgovini i sajmovima autorice Tihane Rubić, u prvom svesku Monografije, str. 331.

114 Isto.

115 Prema podacima iz UEA vunene pokrivače, biljce i šarenice tkali su na horizontalnom tkalačkom stanu, u četiri nita, a sastavljeni su od dvije pole tkanja. (UEA, III, 93, Fd 241/651)
} 


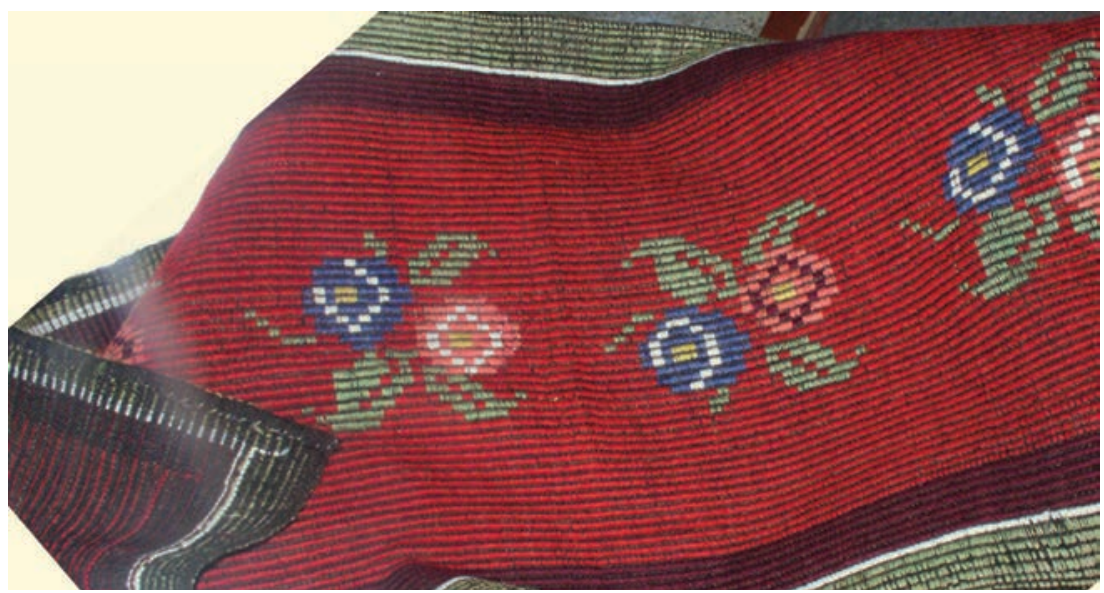

Slika 13: Šarenica, vlasnica Ana Šojat Colaševa, Francikovac; snimio Augustin Perić, srpanj 2005.

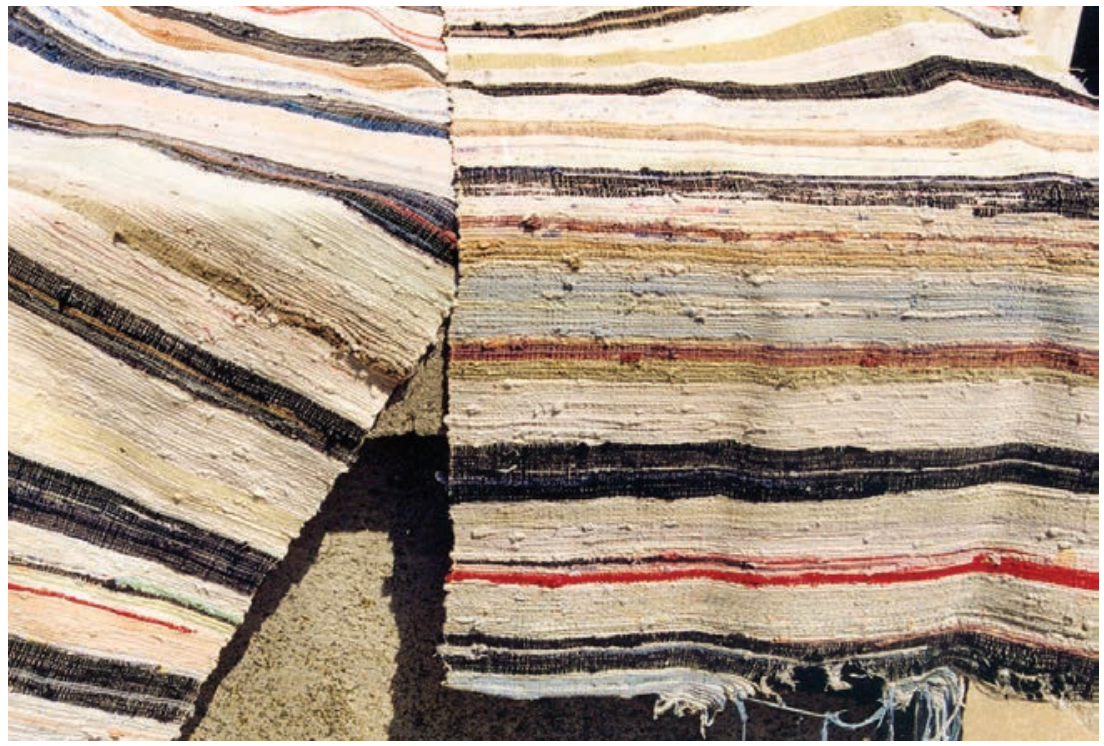

Slika 14: Krpari, vlasnike Ante Šojat Tine; Šojatski Dolac; snimio Augustin Perić, lipanj 2003.

Krpari (sl. 14) su tepisi otkani od starih, već korištenih, krpa, široki $80 \mathrm{~cm}$, a dugački 10 do $20 \mathrm{~m}$. $\mathrm{Uz}$ biljce i šarenice od vune su se izrađivali i madraci. Za takve madrace zabilježen je naziv štramci.

\section{2. ŽENSKI RUČNI RAD}

$\mathrm{V}^{\mathrm{s}}$ ećina odjevnih predmeta na ovom području bila je neukrašena, pa tako i nije zabilježena raznovrsnost tehnika ukrašavanja ili ručnog rada. ${ }^{116}$ Najčešće su bili ukrašavani predmeti uporabnog tekstila poput: jastučnica, ručnika, kuharica (sl. 15) (komad tekstila, najčešće četvrtastog oblika s natpisom, koji su vješali u kuhinji iznad peći), koperti (prekrivač za duple krevete) i sličnih predmeta koje su žene ukrašvale heklanjem ${ }^{117}$ (kukičanjem), šlinganjem ${ }^{118}$ i štikanjem ${ }^{119}$ (vezenjem), odnosno mavezom u boji (tehnika veza koncem u boji, na terenu sinonim za štikanje ${ }^{120}$.

116 Prilikom istraživanja ove teme ženskog ručnog rada cilj je bio utvrditi koje tehnike ukrašavanja tekstila upotrebljavaju Krivopućani. Sam način izrade nisam detaljnije ispitivala, pa će biti potrebno u sljedećim istraživanjima na terenu prikupiti podatke o načinu izrade, kao i o motivima.

117 Od njemačkog hakeln što znači kukičati, u ženskom ručnom radu plesti iglom kukačom. (Klaić 1986:525)

118 Od njemačkog schlingen što znači vesti, a šlingeraj je vezivo, vez i čipka. (Klaić 1986:1298)

119 Od njemačkog sticken što znači vesti. (Klaić 1986:1310)

${ }^{120}$ Mavez je prema Rječniku stranih riječi B. Klaića modri pamuk, tiftik. (Klaić 1986:858) 


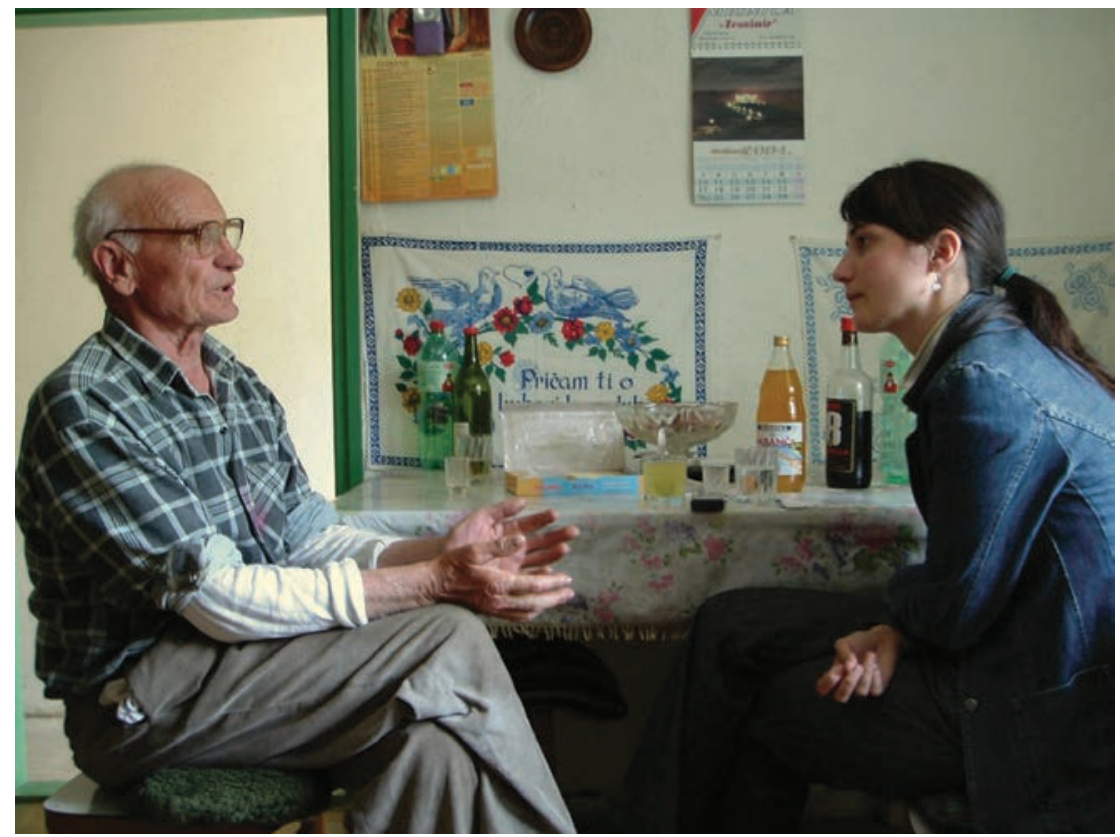

Slika 15: Kuharica u kući Milana Krmpotica Zekonje iz Veljuna, kazivač u razgovoru s Tỉhanom Rubić; snimila Marija Brajković, svibanj 2005.

Heklanje (kukičanje) je pletenje iglom s kukicom. Kukičanjem se najčešće ukrašavalo rubove koperti, plahti i jastučnica, te ručnike. Plahta je mogla biti ukrašena (sl. 16) i neukrašena. Neukrašena plahta služila je za ležanje (sl. 17), dok je ukrašena plahta koja je $s$ jedne strane imala kukičani ukras služila za prekrivanje kreveta. Koperta je imala kukičani ukras s dvije nasuprotne strane i služila je za prekrivanje duplih (bračnih) kreveta. Na kutove jastučnica umetali su kukičani uzorak trokutnog oblika, ispod kojeg su prišivali tkaninu u boji. Osim navedenog, od osamdesetih godina 20. stoljeća Krivopućani češće koriste i heklane stoljnjake, nadstoljnanjake i tabletiće za komode. Osim što se čitavi predmeti izrađuju teknikom heklanja, domaće konopljino i laneno platno ili kupovna žutica, opheklavaju se. (sl. 18a, b)

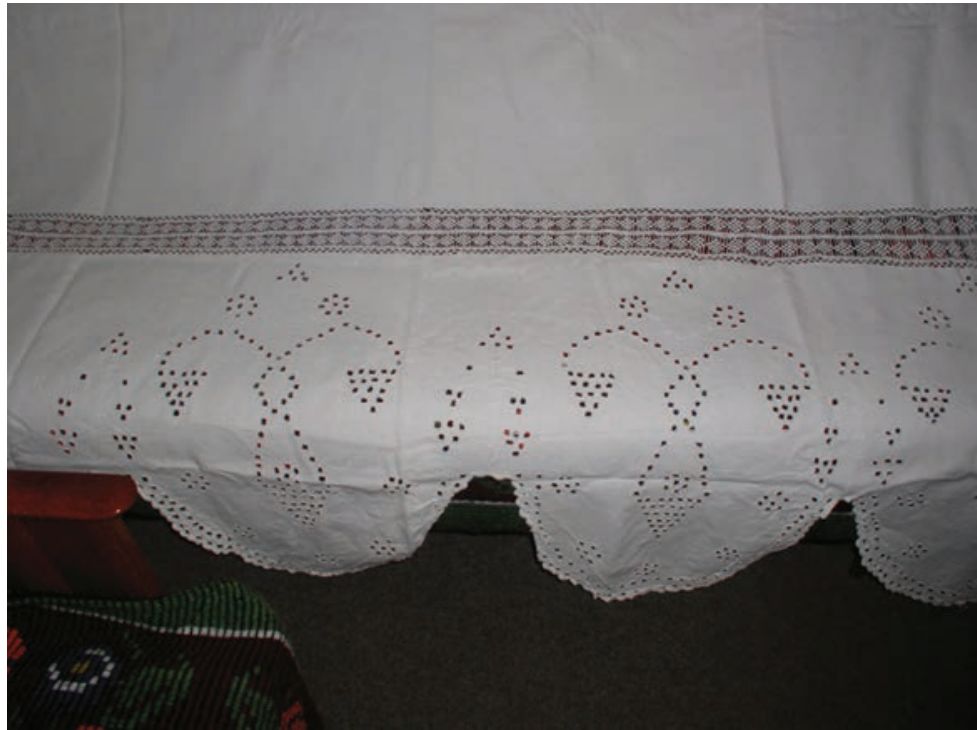

Slika 16: Ukrašen rub plahte, vlasnica Ana Šojat Colaševa, Francikovac; snimio Augustin Perić, srpanj 2005.

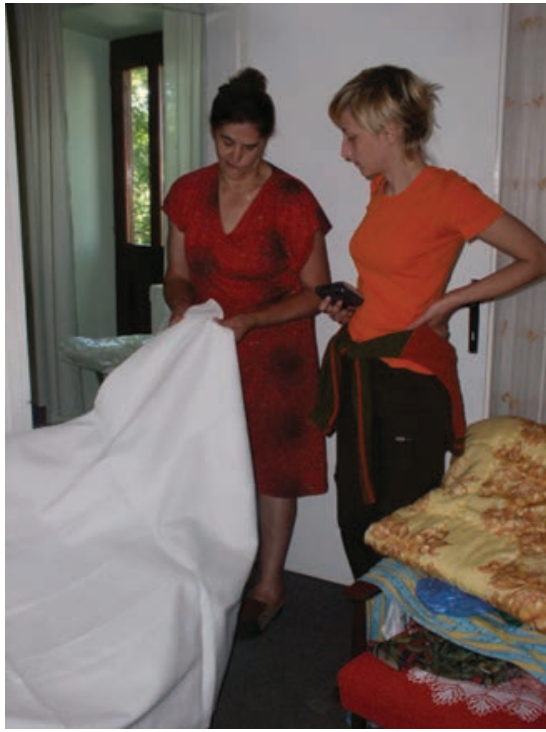

Slikea 17: Kazivačica Ana Šojat Colaševa objašnjava Sanji Lončar upotrebu tekstila, Francikovac; snimila Petra Kelemen, srpanj 2005. 

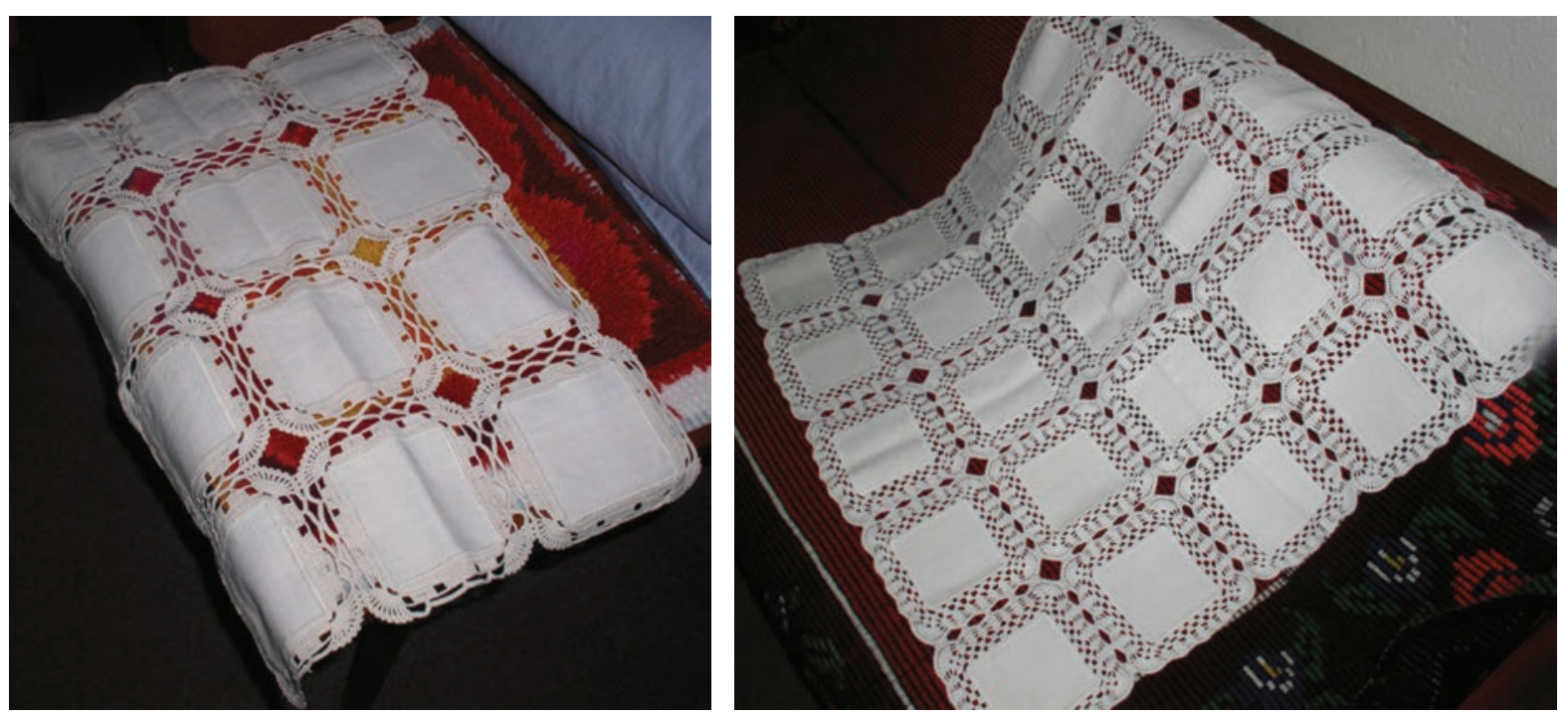

Slika 18a, b: Stolnjak, vlasnica Ana Šojat Colaševa, Francikovac; snimio Augustin Perić, srpanj 2005.

Ručnici i zavjese za vrata ukrašavani su šlinganjem, vrstom bijelog veza s rupicama.

Svi ovi predmeti ukrašavani su i štikanjem, odnosno mavezom, tj. mavezom u boji. Ti nazivi upotrebljavaju se i za ukrašavanje tekstila koncem u boji, tehnikama plosnog veza i vezom križićima. Štikanjem su često izrađivali motive cvijeta, inicijale, pisali puno ime i prezime ili čitav natpis. Na ručnicima je štikanjem vrlo često bilo ispisano: Dobro jutro!, a na kuharicama natpisi poput: Kuharice, dobro kuhaj, ali ipak novce čuvaj!, ili: I najmilijeg gosta tri dana dosta!, ili: Dobro jutro, dragi gosti, u Hrvata se ne posti!

\section{NESTANAK DOMAĆE PROIZVODNJE I POČETAK INTENZIVNE UPORABE KUPOVNIH ODJEVNIH PREDMETA}

$V$ ećina odjevnih predmeta domaće proizvodnje počela se s ovog područja gubiti početkom 20. stoljeća jer su ljudi već tada bili usmjereni na gradska središta, posebno na Senj koji je bio luka i relativno razvijen centar. Takvom je stanju bitno pridonijela i činjenica da je stanovništvo ovog kraja bilo vrlo pokretno, te da je često migriralo u potrazi za sezonskim poslom ${ }^{121}$. Osim toga imali su vrlo razvijenu trgovinu pa je kupovna odjeća i obuća iz drugih područja i zemalja, ovdje vrlo rano prodrla. ${ }^{122}$ Iz tog razloga sjećanje na domaću proizvodnju, kućnu izradu tekstila i odjevnih predmeta, vrlo je slabo jer je ona počela nestajati već dvadesetih i tridesetih godina 20. stoljeća. Ipak, ljudi se danas još uvijek sjećaju svojih sumještanina koji su se tih godina oblačili u tradicijsku odjeću. Tako se sjećaju da se još četrdesetih i pedesetih godina 20. stoljeća nosio kožun. U Stanić Brigu kožune su za vlastite potrebe još šesdesetih i sedamdesetih godina 20. stoljeća tu dolje u selu za sebe izradili neki Juraj i ovdje susjed Mile. ${ }^{123}$ U Matićima se majka Ružice Tonković 1929. godine udala u buštu i vrizu, dok je u Krivom Putu oko 1935. godine jedan stariji Krivopućanin nosio svitice i košulju. Rajtoze su se nosile još pedesetih godina 20. stoljeća. ${ }^{124}$

U selima na području Krivoga Puta kupovna odjeća intenzivno se počela nositi prije Drugoga svjetskoga rata. Za vrijeme i nakon Drugoga svjetskoga rata došlo je do velike ekonomske krize, u već ionako siromašnom kraju, te su se upotrebljavale sve vrste tekstila do kojih se moglo doći. Odjeća se šivala od cerade $^{125}$, šatorskog krila i padobranskog platna. Za ozbiljnije cure (djevojke za udaju) odjeća se šivala od

121 Više o migracijama Krivopućana vidi u prilogu Marijete Rajković u prvom svesku Monografije.

122 Više o trgovini i sajmovima vidi u prilogu Tihane Rubić u prvom svesku Monografije.

123 Josip Prpić Jurina, Stanić Brig.

124 Lucići, Rusova Draga i Stanić Brig.

125 Od talijanskog cerata što znači voštano platno ili navlaka na kolima i vagonima radi zaštite od nevremena. (Klaić 1986:218) 
padobranskog platna, a inače od šatorskog krila. ${ }^{126}$ Nakon tog perioda roba se davala na točkice, tj. dobivala se određena količina materijala po članu obitelji.

\section{ZAKLJUČNA RAZMATRANJA}

$\mathrm{O}$ vim prilogom opisani su tradicijski tekstilni predmeti i rukotvorstvo, istraživani terenskim istraživanjem 2003. godine, a obuhvaćeni su i oni koji se spominju u Upitnicama Etnološkoga atlasa (UEA). U uvodu je obrazložen način korištenja i komparacije podataka iz UEA u tekstu. Navedeni izvori podataka većinom se međusobno potvrđuju, ali ima i razlika. Jedan od razloga vjerojatno je manjkavost Upitnica u pogledu preciznijeg navođenja lokaliteta i vremenskih odrednica. Drugi razlog su propusti prilikom provođenja vlastitih terenskih istraživanja, tijekom kojih se propustilo detaljnije ispitivanje pojedinih dijelova teme.

$\mathrm{Na}$ temelju podataka, dobivenih putem navedenih istraživanja te izvora, u tekstu je u odvojenim poglavljima opisana izrada i obrada sirovine (vuna, lan, konoplja, koža); muška i ženska tradicijska odjeća, obuća i torbe. U zasebnom poglavlju izneseni su i podaci o napuštanju domaće proizvodnje i tradicijske odjeće, te je opisan uporabni tekstil i ženski ručni rad.

Kao sirovine za izradu tradicijske odjeće na području Krivoga Puta najviše su korišteni vuna, lan i konoplja. Vunu za izradu odjeće, nakon striženja, žene su na prelima prvo rasčupale rukama, a zatim obradile pomoću gargaša (češljeva). Tako pripremljenu vunu smotale su u kudilju (smotuljak) i prele. Lan i konoplju su u snopovima, rukovetima, prvo obradili na nožnoj stupi, zatim na trlici i na kraju dodatno na sabljici. Materijal se dalje obrađuje grebenanjem, pomoću grebenova, a zatim ponovno na sabljici. I vunu, i lan, i konoplju, prele su žene pomoću preslice kopljastog tipa. Ispredena nit snovanjem se pripremila za tkanje. Vunu, lan i konoplju žene su nosile tkati u Liku. Kožu su za daljnju uporabu prerađivali strojenjem kukuruznim brašnom i olumom. Od kože su izrađivani kožuni, krzneni ogrtači i šubare.

Ženska odjeća u selima ovog područja sastojala se od donje košulje i vriza, podsuknje. Preko toga žene su nosile haljinu, flajdu, alju. Umjesto haljine mogla se nositi i suknja, vriz, fuštan, kiklja. Preko suknje ili haljine nosile su pregaču, zaslon ili vriz. Za zimu su žene plele maje, džempere s rukavima ili bušte, džempere bez rukava, a preko ramena su prebacile plet, kvadratnu maramu. Ženske čarape su mogle biti kratke, do gležnja (sokne, suknje ili soknje). Za čarape visine do koljena ili nešto ispod koljena, zabilježeni nazivi potkoljenke ili potkolenke, te dokoljenke ili dokolenke. Zabilježena je i uporaba čarapa koje su sezale preko koljena, a nazivali su ih podjednako i čarape i duge čarape.

Muška odjeća sastojala se od svitica, donjih gaća preko kojih su se nosile hlače od kupovnog materijala, rajtoze ili rajt hlače, te košulje. Kaput, ćurak, bio je dužine do bokova, a zabilježena je pojava i dužeg kaputa, kobanice. Ispod kaputa nosio se prsluk, ćerma. Za zimu su žene muškarcima plele maje, džempere s rukavima; pulovere, džempere bez rukava, te čarape. Plele su također i odjevni predmet poput nogavica koji se nosio preko hlača, a sezao je od gležnja do koljena, za koji su zabilježeni nazivi natikače, štrimfe, nakoljenice, te štumfarice. Odjevni predmet sličan prethodnome, ali za ruke, nazivali su zašaknjače ili narukvice.

Glavnu obuću predstavljali su opanci i šlape, vrsta obuće pletena od domaće vune, uz koje su omatali noge obojcima.

$\mathrm{Na}$ temelju kazivanja moglo se zaključiti, kako je u uvodnom dijelu i istaknuto, da Krivopućani svoju tradicijsku odjeću ne percipiraju kao narodnu nošnju. Tradicijsku odjeću, odnosno odjeću domaće proizvodnje, kazivači su opisali kao skromnu odjeću s vrlo malo ukrasnih elemenata koja se nije razlikovala obzirom na dob, odnosno namjenu (blagdanska i svakodnevna/radna odjeća).

Najnovije terensko istraživanje (2003.) u selima na području Krivoga Puta pokazuje kako se Krivopućani relativno slabo sjećaju odjevnih predmeta domaće proizvodnje. Razlog tome je ponajprije rana pojava kupovne odjeće jer je Senj u prvoj polovici 20. stoljeća bio trgovački razvijen grad, a i velik broj

26 Prema kazivanju iz Matića. 
ljudi s ovog područja odlazio je raditi u druge gradove i države. Sve su to razlozi koji su utjecali na to da je većina odjevnih predmeta domaće proizvodnje počela nestajati s područja Krivoga Puta već dvadesetih i tridesetih godina 20. stoljeća. Stoga je i sjećanje o domaćoj proizvodnji, kućnoj izradi tekstila i odjevnih predmeta, vrlo slabo. Ipak, ljudi se danas još uvijek sjećaju svojih sumještanina koji su se tih godina oblačili u pojedine dijelove tradicijske odjeće.

U zasebnom poglavlju osvrnula sam se i na predmete poput biljaca, šarenica i krpara, te kuharica i koperti koji pripadaju skupini uporabnog tekstila, ali su estetski vrlo dojmljivi te su uključeni u prikaz tradicijskog odijevanja na području Krivoga Puta. Prema kazivanjima se može zaključiti da navedene predmete ljudi smatraju izrazitim i specifičnim elementom svoje tradicijske baštine.

Na kraju se može zaključiti kako je tema tekstilnog rukotvorstva i tradicijskog odijevanja na području Krivoga Puta još uvijek nedovoljno istražena i obrađena. Ipak na temelju analize dosad prikupljene građe, može se zaključiti kako je područje Krivoga Puta bilo siromašno i imalo jednostavniju odjeću, bez puno ukrasa, dok su obližnje Primorje i Lika bili bogatiji u pogledu odijevanja. Zbog te jednostavnosti i siromaštva primorski Bunjevci svoje tradicijsko odijevanje nisu doživljavali kao vrijednost, kao svoju nošnju, što je utjecalo na rano napuštanje domaćih odjevnih predmeta, te prihvaćanje kupovnih.

\section{LITERATURA I IZVORI:}

ECKHEL, Nerina (1988): Uzgoj i obrada tekstilnih sirovina i proizvodnja tekstila, u: ur. Jelka Radauš-Ribarić, Dunja Rihtman-Auguštin, Čarolija niti; Vještina narodnog tkanja u Jugoslaviji, MGC, Zagreb, 25-40.

GUŠIĆ, Mirjana (1983): Odjeća Senjskih Uskoka i Bunjevaca, Senjski zbornik, 10/11:73-116, Senj.

KLAIĆ, Bratoljub (1986): Rječnik stranih riječi; Tudice i posudenice, Nakladni zavod Matice hrvatske, Zagreb.

RAJKOVIĆ, Marijeta (2008): Pregled suvremenih migracija Krivopućana, u: Živjeti na Krivom Putu. Etnološko-povijesna monografija o primorskim Bunjevcima, 1. svezak, ur. Milana Černelić, Marijeta Rajković, Tihana Rubić, FF-press, Zagreb, 79-94.

RUBIĆ, Tihana (2008): Tradicijska trgovina i sajmovi, u: Živjeti na Krivom Putu. Etnološko-povijesna monografija o primorskim Bunjevcima, 1. svezak, ur. Milana Černelić, Marijeta Rajković, Tihana Rubić, FF-press, Zagreb, 323-352.

SALVATOR v. HABSBURG, Ludwig (preveo Ljudevit KRMPOTIĆ) (1998): Jahtom Duž hrvatske obale (1870 - 1910), Hrvatski zapisnik, Hannover; Čakovec.

ŠKRBIĆ - ALEMPIJEVIĆ, Nevena (2003): Prilozi poznavanju primorsko-bunjevačkog identiteta, Senjski zbornik 30, Senj, 425-444.

VLATKOVIĆ, Aleksandra (2003): Odijevanje i tekstilno rukotvorstvo primorskih Bunjevaca, Senjski zbornik 30, Senj, 587-628.

Upitnica Etnološkog atlasa (UEA), Svezak II i III, Teme br.: 75. Odjeća i nošnja uopće; 76. Muška i dječja košulja; 77. Muške gaće i hlače; 78. Ženska osnovna odjeća; 79. Muška i ženska gornja odjeća; 80. Ženske i muške pregače i pojasi; 81. Mǔkka i ženska odjeća od krzna; 82. Muška kosa, brkovi i brada i pokrivalo glave; 83. Ženska kosa, oglavlje i pokrivanje glave; 84. Torbe; 85. Obojci, čarape, obuća; 88. Stupe, trlice; 89. Ciš́ćnje vlakana, grebeni; 90. Predenje, preslice, vretena, kolovrati; 91. Sprave za namotavanje niti i snovanje; 92. Tkalački stan; 93. Vrste platna i sukna, načini tkanja, ćilimi i slično; 94. Stupanje sukna i pravljenje pusti; 97. Priredivanje krzna i kože; Fd 241/610; Fd 241/651; Arhiv Odsjeka za etnologiju i kulturnu antropologiju Filozofskog fakulteta Sveučilišta u Zagrebu. 